\title{
Ritual uses of palms in traditional medicine in sub-Saharan Africa: a review
}

\author{
Marta Gruca', Tinde R van Andel ${ }^{2}$ and Henrik Balslev ${ }^{1 *}$
}

\begin{abstract}
Palms (Arecaceae) are prominent elements in African traditional medicines. It is, however, a challenge to find detailed information on the ritual use of palms, which are an inextricable part of African medicinal and spiritual systems. This work reviews ritual uses of palms within African ethnomedicine. We studied over 200 publications on uses of African palms and found information about ritual uses in 26 of them. At least 12 palm species in sub-Saharan Africa are involved in various ritual practices: Borassus aethiopum, Cocos nucifera, Dypsis canaliculata, D. fibrosa, D. pinnatifrons, Elaeis guineensis, Hyphaene coriacea, H. petersiana, Phoenix reclinata, Raphia farinifera, R. hookeri, and R. vinifera. In some rituals, palms play a central role as sacred objects, for example the seeds accompany oracles and palm leaves are used in offerings. In other cases, palms are added as a support to other powerful ingredients, for example palm oil used as a medium to blend and make coherent the healing mixture. A better understanding of the cultural context of medicinal use of palms is needed in order to obtain a more accurate and complete insight into palm-based traditional medicines.
\end{abstract}

Keywords: Arecaceae, Magic plants, Treatment, Healing, Sacred places, Witchcraft

\section{Background}

Traditional medicines in rural sub-Saharan communities recognize that the occurrence of disease can result from the intrusion of negative supernatural forces [1,2]. These forces are often defined as witches, sorcerers, broken taboos, displeased ancestor spirits or deities [3-8]. Afflictions which are mostly related to the action of the malevolent forces are either serious and chronic or emerging suddenly and unexpectedly [4-7]. The patient is often considered a victim, and the therapy must heal not only physical symptoms but also social relationships to liberate the patient from suffering [9]. Thus, traditional healers often apply divination and various rituals in order to understand the overall significance of a healing process and counteract its cause. As a consequence, traditional remedies are not merely used for curing a disease, but are also used to obtain protection or to overcome curses $[3,7,10,11]$.

Palms (family Arecaceae) are prominent in traditional cultures as a source of raw materials for consumption, construction, and other functions of daily life [12-16].

\footnotetext{
* Correspondence: henrik.balslev@biology.au.dk

'Department of Bioscience - Research Group Ecoinformatics and Biodiversity, Aarhus University, Build. 1540, Ny Munkegade 114, DK-8000 Aarhus C, Denmark

Full list of author information is available at the end of the article
}

Traditional remedies are derived from palms throughout the tropics and subtropics to cure many disorders [17-21]. Since palms are part of the everyday life of nearly all rural people in Africa, it may be expected that they are also important in the spiritual framework of rural life in Africa. Even though many studies report ethnomedicinal uses of African palms, from the late nineteenth century $[22,23]$ to very recent times [24] - especially recent studies pay little attention to rituals. In the latest studies on African traditional medicine palms are included among raw lists of plants used for specific ailments [20,25-31]. Detailed preparation and application of palm remedies are rarely mentioned [32-36]. While these types of studies may be useful when searching for potential modern drugs, they do not reveal the ideas underlying the use of the cited medicines nor do they explain why certain plants were selected for a ritual, or their exact therapeutic practice. On the other hand, most of the recent ritual palm use records came from anthropological studies, where the emphasis was put on the explanation of the ritual itself, but the botanical species was not defined [37-39].

Here we focus on palm-derived African ethnomedicine that includes ritual elements. By ritual (or magical treatment) we understand any medicinal practice involving objects (e.g. palm nuts) or behaviors (e.g. incantations) 
believed to have some healing powers and/or ability to counteract or influence the actions of malevolent forces.

We argue that we can only have an accurate insight into traditional medicine if we understand the cultural context of medicinal use of palms (and other plants). In this perspective we address the following specific questions: Which palm species take part in rituals or specific ceremonies? Which palm parts are mostly used? And finally, are palms present in the spiritual framework of African traditional medicines today?

\section{Methods}

In total 26 scientific papers and books on African traditional medicine provided information on ritual uses of palms in Sub-Saharan Africa. This information was extracted and listed with scientific names, plant parts used and detailed use description (Table 1). Our bibliographic search employed several databases, including PubMed, Embase, and Google Scholar. In addition, we conducted a dedicated search with search engines of the State and University Libraries of Aarhus, National Library of Denmark and Copenhagen University Libraries, Mertz Library, and Harvard University Libraries where most of old, limited access literature was studied.

The extracted information was standardized to generally accepted terminology for palm morphology following Dransfield et al. [40]. When oil was given as a palm part used and the author did not mention the scientific name of the palm it was assumed that palm oil was extracted from the African oil palm Elaeis guineensis, since processing of the fruits for edible oil has been traditionally practiced in Africa for thousands of years [41]. Medicinal uses referring to "coconut" were assigned to Cocos nucifera. Some palms remained unidentified, such as those used for "palm wine", which can be produced from various species including Elaeis guineensis, Hyphaene spp., Raphia spp., as well as Phoenix reclinata [41]. Country names referred to in the older literature which are no longer in use, were updated to the current names, i.e., Northern Rhodesia to Zambia, Dahomey to Benin. Species and author names coincide with the World Checklist of Palms [42] and The International Plant Names Index (IPNI) [43] for other plant species. The authors of scientific names of palms are included in Table 2, and authors of other plant species in the (Table 1).

\section{Results}

We found references to ritual uses of at least 12 palm species in sub-Saharan Africa, and they were used for 81 different purposes (for a complete list see the (Table 1). Ritual uses of palms were encountered for 13 different countries and 19 different ethnic groups in the region (Figure 1). The results were organized following the part of palm used.
The palm fruit is made up of three carpels that fuse to form a drupe with one or a few seeds, covered by a thin seed coat. The seed consists mostly of a large oily endosperm which when immature is watery and gelatinous before it turns hard in the mature seed. The seed has a small embryo near one of the germination pores which are thin areas of the bony endocarp. Palm seeds are often called palm kernels or palm nuts [44]. The seed(s) is (are) surrounded by a three layered pericarp consisting of an outer leathery exocarp, a middle fleshy and oily or fibrous mesocarp, and an inner endocarp which may be thick and bony or thin and papery. Palm oil may be extracted from the fleshy mesocarp or from the endosperm of the seed in which case it is called kernel oil. Red palm oil, extracted from Elaeis guineensis fruits, gets its characteristic color from carotenes in the mesocarp, although it can be bleached to produce colorless oil $[41,44]$.

Palm leaves usually are assembled in a rosette at the end of the stem. Each leaf consists of a sheath, a petiole, and a lamina which in turn is made up of a midvein (rachis) and several leaflets (pinnae). In some palms (Cocos, Elaeis, Phoenix, Raphia), the midvein is elongate and has several leaflets that form a pinnate leaf. In other palms (Borassus, Hyphaene), the rachis is reduced and all leaflets radiate from a single point to form a palmate lamina [44]. The uses mentioned below either refer to whole palm leaves or to leaflets, which are dried and used for weaving. In some cases fibers are extracted from the leaflets and used for weaving.

Palms produce a sugary sap for their growth, which is often tapped by humans and used to prepare a fermented beverage called palm wine. Palm sap is extracted from different species, including Cocos nucifera, Borassus aethiopum, and Elaeis guineensis. Tapping is done by cutting the inflorescence and collecting the sap from the injured peduncle or inserting a tube into the palms growing point in the heart of the crown and placing a container at the end of the tube to collect the sap [41].

Roots of palms are adventitious: they originate from the lower part of the stem and are not part of a tap-root system. Therefore, roots can be collected from the palm without the need to dig them out of the ground, and subsequently employed for a variety of purposes [44].

\section{Fruit (palm oil)}

In Zambia, palm fruits were used in prayers before administrating a drug to ensure the effectiveness of medicine and successful recovery of a patient. The Ba-Ila healer used a rattle made of round palm fruits on a handle during ritual therapies [45]. To the Lunda in Zambia, the red color of the mesocarp oil from Elaeis guineensis symbolized power, but it also was interpreted a sign of murder and witchcraft [9]. 
Table 1 Ritual uses of palms in traditional medicine in sub-Saharan Africa, including scientific plant names, plant parts used and detailed use description

\begin{tabular}{|c|c|c|c|c|c|c|c|c|}
\hline $\begin{array}{l}\text { PALM } \\
\text { SPECIES }\end{array}$ & $\begin{array}{l}\text { PART USED } \\
\text { (MENTIONED) }\end{array}$ & $\begin{array}{l}\text { MEDICINE } \\
\text { USED FOR/ACTIVITY }\end{array}$ & PREPARATION & APPLICATION & COUNTRY & $\begin{array}{l}\text { ETHNIC } \\
\text { GROUP }\end{array}$ & REFERENCES & NOTES \\
\hline $\begin{array}{l}\text { Borassus } \\
\text { aethiopum }\end{array}$ & root & Epilepsy & maceration & body bath & Togo & & [65] & $\begin{array}{l}\text { the author adds that epilepsy is } \\
\text { believed to occur mostly during } \\
\text { the full moon (10th to 15th } \\
\text { days of a month) }\end{array}$ \\
\hline B. aethiopum & seed & Scarification & seeds hollowed out & $\begin{array}{l}\text { used as containers for a charred } \\
\text { medicinal mixture called 'katala' in } \\
\text { Haussa. This mixture was rubbed } \\
\text { into skin incisions during } \\
\text { scarification practices }\end{array}$ & Ghana & $\begin{array}{l}\text { Ghana } \\
\text { Haussa }\end{array}$ & [11] & \\
\hline B. aethiopum & root & $\begin{array}{l}\text { Any disease caused } \\
\text { by a curse }\end{array}$ & decoction & drunk & Ghana & Kokomba & $\begin{array}{l}\text { [Gruca, } \\
\text { unpublished] }\end{array}$ & \\
\hline $\begin{array}{l}\text { Cocos } \\
\text { nucifera }\end{array}$ & fruit & $\begin{array}{l}\text { skin rash due to } \\
\text { HIV/AIDS }\end{array}$ & & & Kenya & Suba, Luo & [46] & $\begin{array}{l}\text { the disease is locally known as } \\
\text { 'chira', and its etiology is related } \\
\text { to the transgression of } \\
\text { principles governing sexuality or } \\
\text { seniority; for example: adultery } \\
\text { committed during a wife's } \\
\text { pregnancy, having sexual } \\
\text { intercourse during the harvest, } \\
\text { or failure to observe the proper } \\
\text { separation of sexuality between } \\
\text { generations }\end{array}$ \\
\hline C. nucifera & $\begin{array}{l}\text { whole plant } \\
\text { (palm tree) }\end{array}$ & & planted at sacred places & & Madagascar & Betsimisaraka & [13] & \\
\hline $\begin{array}{l}\text { C. nucifera* + } \\
\text { Elaeis } \\
\text { guineensis* }\end{array}$ & $\begin{array}{l}\text { seed } \\
\text { (coconut) }+ \\
\text { fruit (palm oil) }\end{array}$ & $\begin{array}{l}\text { miscarriage/ } \\
\text { preventive }\end{array}$ & $\begin{array}{l}\text { one tortoise is roasted with } \\
\text { water inside a coco-nut along } \\
\text { with half a bottle of palm oil. } \\
\text { All is roasted until it is almost } \\
\text { burnt and then ground to } \\
\text { powder }\end{array}$ & $\begin{array}{l}\text { the powder is used in a corn } \\
\text { flour pudding, which a woman } \\
\text { should take on rising and going } \\
\text { to bed throughout the course of } \\
\text { one menstruation. The man } \\
\text { should sleep with her five days } \\
\text { after she has finished } \\
\text { menstruating }\end{array}$ & Nigeria & Yoruba & [47] & $\begin{array}{l}\text { for Yoruba tortoise is a symbol } \\
\text { of a prostitute }\end{array}$ \\
\hline $\begin{array}{l}\text { C. nucifera* }+ \\
\text { Unidentified } \\
\text { palm }\end{array}$ & $\begin{array}{l}\text { seed shell + } \\
\text { sap (palm } \\
\text { wine) }\end{array}$ & offering & & $\begin{array}{l}\text { coconut shells filled with palm } \\
\text { wine placed on ancestors' } \\
\text { graves as an offering }\end{array}$ & Kenya & Mijikenda & [62] & \\
\hline E. guineensis & root & epilepsy & $\begin{array}{l}\text { powder, decoction } \\
\text { or burnt powder }\end{array}$ & orally & Togo & & [65] & $\begin{array}{l}\text { the author adds that epilepsy is } \\
\text { believed to occur mostly during } \\
\text { the full moon (10th to 15th } \\
\text { days of a month) }\end{array}$ \\
\hline
\end{tabular}


Table 1 Ritual uses of palms in traditional medicine in sub-Saharan Africa, including scientific plant names, plant parts used and detailed use description (Continued)

\begin{tabular}{|c|c|c|c|c|c|c|c|c|}
\hline E. guineensis & seed (nut) & mental fatigue & $\begin{array}{l}\text { a fresh nut easy to pound or } \\
\text { smash is mixed together with } \\
\text { leaves from Hibiscus surattensis } \\
\text { L., Asystasia gangetica T. } \\
\text { Anderson, Musa } x \text { sapientum L., } \\
\text { NGONGOA, Lopèto and Cyperus } \\
\text { articulates L. }\end{array}$ & $\begin{array}{l}\text { the mixture is rubbed on the } \\
\text { body of the patient. The patient } \\
\text { should be facing the sun during } \\
\text { the treatment and pronounce } \\
\text { "wishes" of good luck. The } \\
\text { residues are put under the } \\
\text { patient's pillow. If he dreams of a } \\
\text { young girl with erected breasts, } \\
\text { there is hope for cure. He should } \\
\text { not wash himself during the rest } \\
\text { of the treatment day }\end{array}$ & Cameroon & & [51] & \\
\hline \multirow[t]{3}{*}{ E. guineensis } & \multirow{3}{*}{$\begin{array}{l}\text { guineensis } \\
\text { seed (nut) }\end{array}$} & \multirow[t]{3}{*}{ oracle rituals } & \multirow{3}{*}{$\begin{array}{l}\text { palm nuts are used for ritual } \\
\text { usages going as far as to be } \\
\text { made sacred at the oracle Fa } \\
\text { (Fon), Ifa (Yoruba), Afan (Ewe) } \\
\text { consulted very often when } \\
\text { looking for the causes of } \\
\text { illnesses and of fate dreams }\end{array}$} & & \multirow[t]{2}{*}{ Benin } & Fon & \multirow[t]{3}{*}[51]{} & \multirow{3}{*}{$\begin{array}{l}\text { The author mentions Togo and } \\
\text { Benin - ethnic groups were } \\
\text { assigned to these countries }\end{array}$} \\
\hline & & & & & & Yoruba & & \\
\hline & & & & & Togo & Ewe & & \\
\hline E. guineensis & leaf (twig) & vulnerability & $\begin{array}{l}\text { ill people carry pieces of palm } \\
\text { twigs around the neck or arm } \\
\text { to get invulnerability }\end{array}$ & & $\begin{array}{l}\text { Togo, } \\
\text { Benin }\end{array}$ & & [51] & \\
\hline E. guineensis & root & $\begin{array}{l}\text { keeping away bad } \\
\text { spirits }\end{array}$ & $\begin{array}{l}\text { roots are associated with the } \\
\text { resin from Daniellia oliveri (Rolfe) } \\
\text { Hutch. \& Dalziel and } \\
\text { Commiphora Africana (A. Rich.) } \\
\text { Endl to keep away the bad spirits }\end{array}$ & & West Africa & & [51] & \\
\hline E. guineensis & infructescence & make children walk & $\begin{array}{l}\text { empty infructescences of Elaeis } \\
\text { guineensis alone or mixed with } \\
\text { ginger (Zingiber officinale Roscoe) } \\
\text { are burned and applied as } \\
\text { magical medicine in the form of } \\
\text { an enema to small children to } \\
\text { encourage them to walk at an } \\
\text { early age }\end{array}$ & & Ghana & & $\begin{array}{l}\text { [van Andel, } \\
\text { unpublished] }\end{array}$ & \\
\hline E. guineensis & inflorescence & $\begin{array}{l}\text { drive away bad } \\
\text { spirits }\end{array}$ & $\begin{array}{l}\text { inflorescences from Elaeis } \\
\text { guineensis are burned so the } \\
\text { smoke drives away bad spirits }\end{array}$ & & Ghana & Akan & {$[7,11]$} & \\
\hline $\begin{array}{l}\text { Elaeis } \\
\text { guineensis } \\
\text { var. idolatrica }\end{array}$ & $\begin{array}{l}\text { whole plant } \\
\text { (palm tree) }\end{array}$ & sacred place & $\begin{array}{l}\text { the palm is protected as sacred } \\
\text { where ever it grows because it is } \\
\text { seen as the realization on earth } \\
\text { of the god Fa. Nobody is } \\
\text { allowed to cut it down or to use } \\
\text { its fruits for making oil. The ritual } \\
\text { use of these palms is reserved for } \\
\text { soothsayers called bokonon }\end{array}$ & & Benin & & [71] & \\
\hline
\end{tabular}


Table 1 Ritual uses of palms in traditional medicine in sub-Saharan Africa, including scientific plant names, plant parts used and detailed use description (Continued)

\begin{tabular}{|c|c|c|c|c|c|c|c|c|}
\hline E. guineensis* & fruit (palm oil) & backache & $\begin{array}{l}\text { the doctor goes in the early } \\
\text { morning to where the mortar } \\
\text { stands. He gets a women to shift } \\
\text { its position, digs down and } \\
\text { removes a piece of any root he } \\
\text { finds there, then he scraps some } \\
\text { dirt from the base of the mortar } \\
\text { itself. The scrapings from the root } \\
\text { and the earth are mixed with } \\
\text { palm oil in a potsherd }\end{array}$ & $\begin{array}{l}\text { the doctor makes the patient lie } \\
\text { across the hole where the root } \\
\text { was removed, then he makes } \\
\text { three lines of cuts with the } \\
\text { razor across the patient's back } \\
\text { where he felt pain and rubs } \\
\text { medicine into the incisions. } \\
\text { After that the patient has to pull } \\
\text { himself upright by means of the } \\
\text { pounding pole that usually } \\
\text { goes with the mortar. He must } \\
\text { then walk to his hut, and leave } \\
\text { the pounding pole upright } \\
\text { against a tree near his hut and } \\
\text { never let it lie on its side }\end{array}$ & Zambia & Lunda & {$[9]$} & $\begin{array}{l}\text { author: "the treatment for } \\
\text { backache appears to be almost } \\
\text { entirely magical" }\end{array}$ \\
\hline E. guineensis* & $\begin{array}{l}\text { fruit (red } \\
\text { palm oil) }\end{array}$ & backache & $\begin{array}{l}\text { first the doctor prepares the } \\
\text { following: a part of a broken hoe } \\
\text { blade and a portion of the } \\
\text { splintered wood from a tree that } \\
\text { has been struck by lightning. After } \\
\text { that he goes to an old village site } \\
\text { to the place where a mortar once } \\
\text { stood for pounding cassava roots } \\
\text { and grain. There he digs and } \\
\text { removes the first root he finds } \\
\text { (any species of tree). The patient } \\
\text { is brought to lie under the } \\
\text { Diplorhynchus condylocarpon } \\
\text { (Müll.Arg.) Pichon tree that is } \\
\text { naturally bent. The doctor scrapes } \\
\text { off bark from underneath the } \\
\text { bend in the tree, and also collects } \\
\text { some scrapings from the upper } \\
\text { side. Then he places a pounding } \\
\text { pole at right angles to the tree. } \\
\text { Then he adds to the medicine } \\
\text { some scrapings from the top of a } \\
\text { tortoise's shell. Then the doctor } \\
\text { brings a potsherd in which he } \\
\text { puts red palm oil. He scrapes } \\
\text { some iron dust from the broken } \\
\text { hoe on to the oil. Then he burns } \\
\text { the piece of lightning-struck tree } \\
\text { and adds its ash to the mixture. In } \\
\text { go the tortoise shell scrapings } \\
\text { and finally the scrapings from the } \\
\text { tree. The medicine is thoroughly } \\
\text { mixed with the oil }\end{array}$ & $\begin{array}{l}\text { the doctor makes two or three } \\
\text { lines of small incisions across } \\
\text { the patient's back, where the } \\
\text { pain is. When the blood begins } \\
\text { to ooze, the doctor rubs the } \\
\text { medicine into those cuts. } \\
\text { Afterwards the doctor takes the } \\
\text { pounding pole and presses it } \\
\text { on the patient's back where the } \\
\text { incisions are. He presses the } \\
\text { pestle lengthwise on the back } \\
\text { with both hands. Subsequently } \\
\text { the patient has to hold the } \\
\text { pounding pole up vertically and } \\
\text { go under the crook in the } \\
\text { Diplorrhyncus condylocarpon } \\
\text { tree. The patient has to } \\
\text { straighten himself up, with the } \\
\text { help of the pounding pole and } \\
\text { push the tree up with his back. } \\
\text { Then he must address the tree: } \\
\text { "I have already left this disease } \\
\text { with you. I must go home } \\
\text { feeling no more pain, because I } \\
\text { have left it already with you". } \\
\text { The patient returns home } \\
\text { bearing the pounding pole }\end{array}$ & Zambia & Lunda & [9] & $\begin{array}{l}\text { symbolic explanation of the } \\
\text { ritual from the author: broken } \\
\text { hoe blade snaps suddenly } \\
\text { when people are digging; in } \\
\text { the same way the person with } \\
\text { backache feels as though he } \\
\text { has suddenly been broken. A } \\
\text { meal mortar is used because of } \\
\text { the pounding, this represents } \\
\text { hitting and having backache is } \\
\text { like being hit very hard. A } \\
\text { tortoise shell is used because it } \\
\text { is hard and this medicine } \\
\text { strengthens the back. The tree } \\
\text { used has a white gum so it is } \\
\text { white or lucky tree, the } \\
\text { whiteness of the tree gives the } \\
\text { patient health (color symbols } \\
\text { among Ndmebu) }\end{array}$ \\
\hline
\end{tabular}


Table 1 Ritual uses of palms in traditional medicine in sub-Saharan Africa, including scientific plant names, plant parts used and detailed use description

(Continued)

\begin{tabular}{|c|c|c|c|c|c|c|c|c|}
\hline E. guineensis* & fruit (palm oil) & medico-magic & $\begin{array}{l}\text { leaves of Hyptis lanceolata Poir. } \\
\text { mixed with palm oil }\end{array}$ & & Gabon & Masango & [49] & \\
\hline E. guineensis* & $\begin{array}{l}\text { seed (palm } \\
\text { kernel oil) }\end{array}$ & scarification wounds & $\begin{array}{l}\text { two loops of the split vine used, } \\
\text { one left with a flat sharp edge } \\
\text { for scrapping off the pus, the } \\
\text { other pounded to make a soft } \\
\text { brush loop with which the } \\
\text { dressing is completed. The juice } \\
\text { of Rothmannia whitfieldii (Lindl.) } \\
\text { Dandy (cited as Randia } \\
\text { malleifera) is rubbed in to cause } \\
\text { a slight formation of keloid }\end{array}$ & $\begin{array}{l}\text { The boy is told to lie on his mat } \\
\text { first on one side, then on his } \\
\text { face, then on the other side, } \\
\text { then on his back, changing his } \\
\text { position often to avoid uneven } \\
\text { scarring, and bad sores. After a } \\
\text { few days the wounds are } \\
\text { dressed with palm kernel oil } \\
\text { applied with a brush of owl's } \\
\text { feathers }\end{array}$ & Liberia & Mano/Poro & {$[48]$} & \\
\hline E. guineensis* & $\begin{array}{l}\text { fruit (red palm } \\
\text { oil) }\end{array}$ & fractures & $\begin{array}{l}\text { a stick from each of the } \\
\text { following trees or shrubs is } \\
\text { calcined: cited as Ricinodendron } \\
\text { africanum Pierre ex Pax, Dracena } \\
\text { sp., Whitfieldia lateritia Hook. } \\
\text { and any small twig broken over } \\
\text { with the break healed so that } \\
\text { the stick is growing in the } \\
\text { twisted or bent position. The } \\
\text { calcined wood is powdered and } \\
\text { mixed with the red palm oil }\end{array}$ & $\begin{array}{l}\text { the ointment is rubbed on the } \\
\text { area over the fracture }\end{array}$ & Liberia & Mano & {$[48]$} & \\
\hline E. guineensis* & $\begin{array}{l}\text { fruit (red } \\
\text { palm oil) }\end{array}$ & hiccough & $\begin{array}{l}\text { a whole vine of Clerodendron } \\
\text { sp. is calcined and beaten to } \\
\text { powder. This powder is kept in } \\
\text { a small horn, and a small } \\
\text { amount mixed with red palm } \\
\text { oil }\end{array}$ & eaten & Liberia & Mano & {$[48]$} & $\begin{array}{l}\text { author: "charred drug is } \\
\text { magical" }\end{array}$ \\
\hline E. guineensis* & $\begin{array}{l}\text { fruit (red } \\
\text { palm oil) }\end{array}$ & palpitation & $\begin{array}{l}\text { an inflorescence of Costus sp. is } \\
\text { peeled; then a handful of } \\
\text { Harungana madagascariensis } \\
\text { Poir. buds is added - all beaten } \\
\text { up in a mortar. Some of the } \\
\text { mixture is put in an iron spoon } \\
\text { with red palm oil, four pebbles } \\
\text { are heated in the fire (three if } \\
\text { for a woman) and dropped into } \\
\text { the spoon }\end{array}$ & the patient licks the spoon & Liberia & Mano & [48] & numeric symbols \\
\hline E. guineensis* & fruit (palm oil) & $\begin{array}{l}\text { heart trouble, } \\
\text { rapid pulse }\end{array}$ & $\begin{array}{l}\text { a young shoot of unidentified } \\
\text { plant is beaten up to a pulp and } \\
\text { put in the spoon with a little } \\
\text { palm oil. Three (or four) pebbles } \\
\text { are heated in the fire and added } \\
\text { to the spoon, stirred until cool - } \\
\text { all done in the morning before } \\
\text { the patient has eaten }\end{array}$ & $\begin{array}{l}\text { the patient takes the contents } \\
\text { of the spoon into his mouth } \\
\text { spitting out the stones far away } \\
\text { and swallowing the pulp. What } \\
\text { is left on the spoon is rubbed } \\
\text { over the pericordium }\end{array}$ & Liberia & Mano & [48] & numeric symbols \\
\hline
\end{tabular}


Table 1 Ritual uses of palms in traditional medicine in sub-Saharan Africa, including scientific plant names, plant parts used and detailed use description (Continued)

\begin{tabular}{|c|c|c|c|c|c|c|c|c|}
\hline E. guineensis* & $\begin{array}{l}\text { fruit (red palm } \\
\text { oil) }\end{array}$ & $\begin{array}{l}\text { rheumatism } \\
\text { (due to yaws) }\end{array}$ & $\begin{array}{l}\text { a small horn is filled with } \\
\text { powdered charcoal from various } \\
\text { plants mixed with red palm oil } \\
\text { and leaves beaten to pulp }\end{array}$ & & Liberia & Mano & [48] & $\begin{array}{l}\text { author's explanation of } \\
\text { symbolism: 'This is an example } \\
\text { of blending "male" and "female" } \\
\text { elements in a mixture to form a } \\
\text { more powerful medicine. The } \\
\text { leaves and bark of living plants } \\
\text { and the red palm oil are } \\
\text { supposed to represent the } \\
\text { active male elements; the } \\
\text { charred stems of other plants } \\
\text { and "burned" oil ... are } \\
\text { supposed to represent the } \\
\text { attenuated, magical, kore } \\
\text { zxpreventive female elements' }\end{array}$ \\
\hline E. guineensis* & fruit (palm oil) & $\begin{array}{l}\text { respiratory pain } \\
\text { due to pleurisy }\end{array}$ & $\begin{array}{l}\text { a doctor takes a handful of } \\
\text { Bidens pilosa L. (cited as Spanish } \\
\text { needle), burns to ashes and } \\
\text { mixes the ashes with palm oil }\end{array}$ & $\begin{array}{l}\text { doctor and the patient sit facing } \\
\text { each other, a doctor rubs the } \\
\text { ointment on his hands, make two } \\
\text { false passes around the patient's } \\
\text { chest from back to front, then } \\
\text { with the third he rubs hard (or } \\
\text { fourth if it is a man). He gets a } \\
\text { good hold for this last rub to lift a } \\
\text { tremendous weight, pulls forward, } \\
\text { and with what seems to be a } \\
\text { great effort, rubs the sickness out } \\
\text { and wipes it off on a bit of trash } \\
\text { which he throws away }\end{array}$ & Liberia & Mano & {$[48]$} & numeric symbols \\
\hline E. guineensis* & $\begin{array}{l}\text { fruit (red } \\
\text { palm oil) }\end{array}$ & influenza & $\begin{array}{l}\text { a handful of thorns of } \\
\text { Combretum grandiflorum G.Don } \\
\text { is burned to charcoal in a pot, } \\
\text { then heated with red palm oil }\end{array}$ & $\begin{array}{l}\text { used to anoint the ankles, } \\
\text { knees, and elbows }\end{array}$ & Liberia & Mano & {$[48]$} & $\begin{array}{l}\text { "this remedy was originally } \\
\text { revealed in a dream, probably } \\
\text { suggested by the flaming } \\
\text { suddenness of blooming of the } \\
\text { great red panicles of this vine as } \\
\text { resembling the appearance of } \\
\text { the epidemic." }\end{array}$ \\
\hline E. guineensis* & fruit (palm oil) & acute hepatitis & $\begin{array}{l}\text { a piece of a large shelf fungus } \\
\text { shaped like a liver is charred, } \\
\text { powdered and mixed with } \\
\text { palm oil }\end{array}$ & rubbed over the liver & Liberia & Mano & {$[48]$} & $\begin{array}{l}\text { shape of the fungus is the } \\
\text { shape of the organ cured }\end{array}$ \\
\hline E. guineensis* & $\begin{array}{l}\text { fruit (red } \\
\text { palm oil) }\end{array}$ & coma & $\begin{array}{l}\text { a knot of the parasite Loranthus } \\
\text { micranthus Hook.f. where it joins } \\
\text { the host branch is calcined and } \\
\text { triturated in an iron pot. The } \\
\text { black powder is mixed with red } \\
\text { palm oil }\end{array}$ & $\begin{array}{l}\text { rubbed on the patient's cheeks } \\
\text { toward the mouth and he will } \\
\text { talk }\end{array}$ & Liberia & Mano & [48] & \\
\hline
\end{tabular}


Table 1 Ritual uses of palms in traditional medicine in sub-Saharan Africa, including scientific plant names, plant parts used and detailed use description

(Continued)

\begin{tabular}{|c|c|c|c|c|c|c|c|}
\hline E. guineensis* & $\begin{array}{l}\text { fruit (red } \\
\text { palm oil) }\end{array}$ & coma & $\begin{array}{l}\text { a medicine to give the cow's } \\
\text { tail (see application) its magical } \\
\text { power is made as follows: a } \\
\text { piece of the length of a finger } \\
\text { of any branch broken off by } \\
\text { wind but lodged before it } \\
\text { reached the ground, a pinch of } \\
\text { the flowers of Parkia biglobosa } \\
\text { Benth., a bit of the vine of Piper } \\
\text { guineense Schumach. and some } \\
\text { other plants (names unknown) - } \\
\text { all is calcined in a pot and tritu- } \\
\text { rated with a stick. Red palm oil } \\
\text { is added and some of the black } \\
\text { paste is put into the little horn }\end{array}$ & $\begin{array}{l}\text { a snake doctor brings the } \\
\text { prepared cow's tail and he } \\
\text { brushes the sick man's face and } \\
\text { asks him a question. If he does } \\
\text { not answer it means he will die. If } \\
\text { he answers the doctor dips his } \\
\text { left third finger into a small horn } \\
\text { tied to the cow's tail, gets some } \\
\text { medicine and rubs it over the } \\
\text { patient's heart saying: 'this is my } \\
\text { own medicine... I will make you } \\
\text { well'. After that the doctor } \\
\text { proceeds to make medicine for } \\
\text { whatever sickness the patient had } \\
\text { to start with }\end{array}$ & Liberia & Mano & [48] \\
\hline E. guineensis* & $\begin{array}{l}\text { fruit (red } \\
\text { palm oil) }\end{array}$ & amenorrhea & $\begin{array}{l}\text { Three seeds of Ricinodendron } \\
\text { heudelotii subsp. africanum (Müll. } \\
\text { Arg.) J.Léonard (cited as } \\
\text { Ricinodendron africanum) and a } \\
\text { quantity of canna blooms Canna } \\
\text { indica L. (cited as Canna } \\
\text { bidentata) are beaten together in } \\
\text { a mortar, and put into a big } \\
\text { spoon. Then a little salt and red } \\
\text { palm oil (freshly prepared, not } \\
\text { refined by heating) is added. } \\
\text { Three pebbles are put in the fire } \\
\text { and allowed to get hot, then one } \\
\text { of these "rocks" is put into the } \\
\text { spoon and stirred until it has } \\
\text { cooled, and then discarded. The } \\
\text { same process is repeated with } \\
\text { two other rocks }\end{array}$ & $\begin{array}{l}\text { Woman starts up the ladder-stick } \\
\text { towards the loft and stands with } \\
\text { both feet on the first notch and } \\
\text { she dips her fingers into the } \\
\text { spoon and lick off the medicine. } \\
\text { She will have her menstrual } \\
\text { function restored in two or three } \\
\text { days }\end{array}$ & Liberia & Mano & [48] \\
\hline E. guineensis* & $\begin{array}{l}\text { fruit (red } \\
\text { palm oil) }\end{array}$ & gonorrheal orchitis & $\begin{array}{l}\text { A doctor takes a piece of the } \\
\text { bark of Erythrina latissima E.Mey } \\
\text { with two of the conical thorns } \\
\text { still adherent. He scrapes off the } \\
\text { inner bark and chews it up with } \\
\text { a few grains of Aframomum } \\
\text { angustifolium K.Schum. (cited as } \\
\text { Amomum melagueta) }\end{array}$ & $\begin{array}{l}\text { First a doctor tells the patient to } \\
\text { 'wash the thing'. Holding the } \\
\text { scrotum in both hands he blows } \\
\text { his medicine from his mouth } \\
\text { onto it, then he breaks off the } \\
\text { two thorns from the bark, } \\
\text { calcines them and mixes the } \\
\text { powder with red palm oil, and } \\
\text { rubs it on the scrotum. In two or } \\
\text { three days the swelling will go } \\
\text { down }\end{array}$ & Liberia & Mano & [48] \\
\hline
\end{tabular}


Table 1 Ritual uses of palms in traditional medicine in sub-Saharan Africa, including scientific plant names, plant parts used and detailed use description

\section{(Continued)}

\begin{tabular}{|c|c|c|c|c|c|c|c|c|}
\hline E. guineensis* & fruit (palm oil) & gonorrhea & $\begin{array}{l}\text { Bark fibers of Waltheria } \\
\text { americana L. are twisted into a } \\
\text { cord to be worn around the } \\
\text { waist. The cord and loin cloth are } \\
\text { smeared with an ointment made } \\
\text { of the flower stalks of Cyathula } \\
\text { prostrata Blume, fried black, and } \\
\text { ground up with palm oil }\end{array}$ & worn around the waist & Liberia & Mano & {$[48]$} & \\
\hline E. guineensis* & fruit (palm oil) & tinea cruris & $\begin{array}{l}\text { Ointment made of some plant } \\
\text { (name unclear) and charred big } \\
\text { black ants- ground with palm } \\
\text { oil }\end{array}$ & ointment & Liberia & Mano & [48] & \\
\hline E. guineensis* & fruit (palm oil) & chronic ulcers & $\begin{array}{l}\text { Leaves of the variety of } \\
\text { Combretum aculeatum Vent. } \\
\text { growing on dry ground are } \\
\text { fried in palm oil with a finger } \\
\text { ring in the pot }\end{array}$ & $\begin{array}{l}\text { the mass is rubbed on the legs } \\
\text { and the ring is worn }\end{array}$ & Liberia & Mano & {$[48]$} & \\
\hline E. guineensis* & $\begin{array}{l}\text { fruit (red } \\
\text { palm oil) }\end{array}$ & snake bites & $\begin{array}{l}\text { a piece of every sort of thorny } \\
\text { shrub or scratchy vine is } \\
\text { collected and all calcined in a } \\
\text { pot, beaten to a black powder } \\
\text { in a mortar and mixed with red } \\
\text { palm oil. The medicine is put } \\
\text { into a horn or into a big acatma } \\
\text { snail shell. Only the horn of the } \\
\text { black antelope (Cephalopus } \\
\text { niger) is a taboo for this } \\
\text { purpose. Leaves of Mareya } \\
\text { spicata Baill. are beaten up with } \\
\text { clay and a little put in the horn } \\
\text { before it is filled with a calcined } \\
\text { mixture }\end{array}$ & $\begin{array}{l}\text { a horn decorated with bracelets } \\
\text { is carried by the snake man. The } \\
\text { medicine is smeared on the } \\
\text { legs if going onto the forest at } \\
\text { night without the light. If the } \\
\text { snake bites the snake man will } \\
\text { not be hurt. The medicine is } \\
\text { said to kill the snake if rubbed } \\
\text { on its head. This medicine is } \\
\text { also used as an emergency } \\
\text { treatment for any snakebite. A } \\
\text { little eaten and rubbed on the } \\
\text { wound is thought to be } \\
\text { efficient first-aid treatment }\end{array}$ & Liberia & $\begin{array}{l}\text { Mano/Ba } \\
\text { Kona }\end{array}$ & {$[48]$} & \\
\hline E. guineensis* & $\begin{array}{l}\text { fruit (red } \\
\text { palm oil) }\end{array}$ & control of snakes & $\begin{array}{l}\text { leaves of Mareya spicata Baill. are } \\
\text { calcined and mixed with red } \\
\text { palm oil. The black ointment is } \\
\text { put into a horn }\end{array}$ & $\begin{array}{l}\text { when a snake is seen on a tree, } \\
\text { some of the black ointment is } \\
\text { taken and rubbed around the } \\
\text { tree trunk saying 'gbaka'. The } \\
\text { snake is supposed to fall down } \\
\text { out of the tree, and be easily } \\
\text { killed. If there is no stick handy } \\
\text { to kill the snake with, a person } \\
\text { should rub the ointment on } \\
\text { both hands, grab the snake by } \\
\text { tail and beat it against the } \\
\text { ground }\end{array}$ & Liberia & $\begin{array}{l}\text { Mano/Ba } \\
\text { Kona }\end{array}$ & [48] & $\begin{array}{l}\text { the author mentions that this } \\
\text { procedure is probably all } \\
\text { magical except the act of } \\
\text { beating the snake on the } \\
\text { ground }\end{array}$ \\
\hline
\end{tabular}


Table 1 Ritual uses of palms in traditional medicine in sub-Saharan Africa, including scientific plant names, plant parts used and detailed use description (Continued)

\begin{tabular}{|c|c|c|c|c|c|c|c|c|}
\hline E. guineensis* & $\begin{array}{l}\text { fruit (red } \\
\text { palm oil) }\end{array}$ & $\begin{array}{l}\text { protection for } \\
\text { women }\end{array}$ & $\begin{array}{l}\text { calcined twig of Protomegabaria } \\
\text { stapfiana Hutch. (mentioned as } \\
\text { Protomegabaria staphiana) } \\
\text { mixed with red palm oil and } \\
\text { salt and put into a horn }\end{array}$ & $\begin{array}{l}\text { any woman member of the } \\
\text { snake society has a horn of this } \\
\text { medicine tied to her waist to } \\
\text { keep her from getting sick as a } \\
\text { result of her contact with the } \\
\text { snake people when she attends } \\
\text { a meeting to sing and dance. } \\
\text { She may lick the medicine from } \\
\text { the end of the finger if she feels } \\
\text { dizzy or afraid }\end{array}$ & Liberia & $\begin{array}{l}\text { Mano/Ba } \\
\text { Kona }\end{array}$ & [48] & $\begin{array}{l}\text { the author mentions that these } \\
\text { practices are highly magical }\end{array}$ \\
\hline E. guineensis* & fruit (palm oil) & $\begin{array}{l}\text { protective medicine } \\
\text { and fetishes }\end{array}$ & $\begin{array}{l}\text { when preparing the Poro session } \\
\text { the ritual of feeding the fetish } \\
\text { had to be made: with cooked } \\
\text { rice, the gizzard cut into bits and } \\
\text { some palm oil, saying: "(...) Let } \\
\text { all people come here so we can } \\
\text { be prosperous" }\end{array}$ & see preparation & Liberia & $\begin{array}{l}\text { Mano/Ba } \\
\text { Kona }\end{array}$ & {$[48]$} & \\
\hline E. guineensis* & fruit (palm oil) & malaria & & $\begin{array}{l}\text { shea butter (Vitellaria paradoxa C. } \\
\text { F.Gaertn.) is used to make a ring } \\
\text { around the neck. Underneath } \\
\text { another ring with palm oil is } \\
\text { made. If a patient is a female, a } \\
\text { doctor puts left hand on her } \\
\text { head; and right hand if it is a } \\
\text { man. Then the following } \\
\text { incantation is recited: "The } \\
\text { mosquito with six children is the } \\
\text { name given to the blacksmith } \\
\text { who makes headache (repeat } \\
\text { thrice). Two of the children went } \\
\text { to a white tree, two went to a } \\
\text { Kogbe tree, the last two were } \\
\text { sent by Orunmila [the deity] to } \\
\text { go and beat the kiriji drum on } \\
\text { the heads of human beings. But } \\
\text { Orunmila ordered that this drum } \\
\text { should not be beaten on the } \\
\text { head of those patients that make } \\
\text { this mark of shea butter and oil } \\
\text { around their neck. Because of } \\
\text { this, [name of the patient] whose } \\
\text { neck has been marked around } \\
\text { with shea butter and oil should } \\
\text { be quickly spared" }\end{array}$ & Nigeria & Yoruba & {$[47]$} & $\begin{array}{l}\text { the author mentions this } \\
\text { treatment is for high } \\
\text { temperature and severe } \\
\text { headache, but makes a note } \\
\text { that this is probably equivalent } \\
\text { to Western malariology }\end{array}$ \\
\hline
\end{tabular}


Table 1 Ritual uses of palms in traditional medicine in sub-Saharan Africa, including scientific plant names, plant parts used and detailed use description (Continued)

\begin{tabular}{|c|c|c|c|c|c|c|c|}
\hline E. guineensis* & fruit (palm oil) & smallpox & $\begin{array}{l}\text { leaves of Kalanchoe sp., leaves of } \\
\text { Peperomia pellucida Kunth. and } \\
\text { powdered snail shells are mixed } \\
\text { into an oily base consisting of } \\
\text { palm oil and shea butter. } \\
\text { Preparation of the ointment is } \\
\text { accompanied by the long } \\
\text { incantation. A particular Ifa sign } \\
\text { (from Ifa-oracle divination) } \\
\text { should be made upon the } \\
\text { surface of the calabash containing } \\
\text { the ingredients }\end{array}$ & $\begin{array}{l}\text { the resulting ointment is } \\
\text { efficacious in reducing pock } \\
\text { marks or scarring }\end{array}$ & Nigeria & Yoruba & {$[47]$} \\
\hline E. guineensis* & fruit (palm oil) & offerings & $\begin{array}{l}\text { palm oil is offered to a variety } \\
\text { of vodun spirits. For the annual } \\
\text { yam celebration, Legba - the } \\
\text { guardian spirit, is offered yams, } \\
\text { palm oil, chicken blood, and } \\
\text { other offerings. Throughout } \\
\text { coastal Benin palm oil is also } \\
\text { used in vo, which are sacrifices } \\
\text { or offerings used in daily } \\
\text { problem solving. An example of } \\
\text { vo is a calabash containing kola } \\
\text { nuts, palm oil, and other items } \\
\text { indicated by the diviner. It is } \\
\text { placed in the center of a paved } \\
\text { road, and by end of the day it is } \\
\text { run over by cars, so the } \\
\text { problems are destroyed }\end{array}$ & & Benin & & {$[37]$} \\
\hline E. guineensis* & fruit (palm oil) & offerings & $\begin{array}{l}\text { near almost every door there } \\
\text { used to stand the Legba-pot, filled } \\
\text { every morning and evening with } \\
\text { cooked maize and palm oil. And } \\
\text { upon the vodun called the } \\
\text { "Vulture's Dish" the passers-by used } \\
\text { to deposit a little food or palm oil, } \\
\text { to bring luck or ward off danger }\end{array}$ & & Benin & & {$[50]$} \\
\hline $\begin{array}{l}\text { E.guineensis* } \\
+ \\
\text { Unidentified } \\
\text { palm }\end{array}$ & $\begin{array}{l}\text { fruit (red palm } \\
\text { oil) + sap } \\
\text { (palm wine) }\end{array}$ & black magic - poison & $\begin{array}{l}\text { a bark of a tree from Rutaceae } \\
\text { family is mixed with young } \\
\text { branches of Mimosa sp. and } \\
\text { Byrsocarpus coccineus Schumach., } \\
\text { thoroughly roasted in a pot, } \\
\text { beaten to powder and mixed } \\
\text { with red palm oil and crocodile } \\
\text { gall. Kept in a horn of the black } \\
\text { antelope. A little of a poison is put } \\
\text { under the thumb-nail and placed } \\
\text { in the palm wine }\end{array}$ & see preparation & Liberia & Mano & {$[48]$} \\
\hline
\end{tabular}


Table 1 Ritual uses of palms in traditional medicine in sub-Saharan Africa, including scientific plant names, plant parts used and detailed use description (Continued)

\begin{tabular}{|c|c|c|c|c|c|c|c|}
\hline $\begin{array}{l}\text { Dypsis } \\
\text { canaliculata }\end{array}$ & $\begin{array}{l}\text { whole plant } \\
\text { (palm tree) }\end{array}$ & & $\begin{array}{l}\text { palm tree planted at sacred } \\
\text { places }\end{array}$ & & Madagascar & Betsimisaraka & [13] \\
\hline $\begin{array}{l}\text { Dypsis } \\
\text { fibrosa }\end{array}$ & leaf & festivities & & $\begin{array}{l}\text { leaves used to decorate houses } \\
\text { at clerical festivities }\end{array}$ & Madagascar & Betsimisaraka & [14] \\
\hline $\begin{array}{l}\text { Dypsis } \\
\text { pinnatifrons }\end{array}$ & leaf & festivities & & $\begin{array}{l}\text { leaves used in decoration of } \\
\text { churches, and pinnae to } \\
\text { manufacture crosses for churches }\end{array}$ & Madagascar & Betsimisaraka & {$[13]$} \\
\hline $\begin{array}{l}\text { Hyphaene } \\
\text { coriacea }\end{array}$ & leaf & $\begin{array}{l}\text { circumcision } \\
\text { ceremony }\end{array}$ & & $\begin{array}{l}\text { leaves are tied to legs of boys } \\
\text { and heads of women during } \\
\text { circumcision ceremony }\end{array}$ & Kenya & Camus & {$[57]$} \\
\hline $\begin{array}{l}\text { Hyphaene } \\
\text { coriacea }\end{array}$ & leaf & ritual & & $\begin{array}{l}\text { leaves used to prepare bridal } \\
\text { hats }\end{array}$ & Namibia & Ovambo & {$[58]$} \\
\hline $\begin{array}{l}\text { Phoenix } \\
\text { reclinata }\end{array}$ & leaf & $\begin{array}{l}\text { ceremonial and } \\
\text { religious purposes }\end{array}$ & & & Uganda & & [59] \\
\hline $\begin{array}{l}\text { Raphia } \\
\text { farinifera }\end{array}$ & leaf & festivities & & $\begin{array}{l}\text { leaves are utilized for making } \\
\text { crosses, and they are burned as } \\
\text { incent at church }\end{array}$ & Madagascar & Betsimisaraka & [13] \\
\hline $\begin{array}{l}\text { Raphia } \\
\text { hookeri }\end{array}$ & seed & ritual baby care & $\begin{array}{l}\text { the seeds of Raphia hookeri are } \\
\text { used to treat the baby's fontanel } \\
\text { that "beats". The seeds are } \\
\text { roasted over the fire till they are } \\
\text { black as coal, ground to powder, } \\
\text { mixed with some unknown } \\
\text { ingredient (perhaps oil) and the } \\
\text { mixture is smeared on the } \\
\text { fontanel }\end{array}$ & & $\begin{array}{l}\text { Ghana and } \\
\text { Benin }\end{array}$ & & [54] \\
\hline $\begin{array}{l}\text { Raphia } \\
\text { vinifera }\end{array}$ & leaf & $\begin{array}{l}\text { against witchcraft, or } \\
\text { any member who } \\
\text { recently had sexual } \\
\text { intercourse/ } \\
\text { preventive }\end{array}$ & $\begin{array}{l}\text { a curtain made of bud leaves } \\
\text { of Raphia vinifera }\end{array}$ & $\begin{array}{l}\text { a curtain is a barrier set up across } \\
\text { the road leading to the secret } \\
\text { place of a meeting. It is effective } \\
\text { against any outsider that may } \\
\text { bring witchcraft medicine, } \\
\text { poison, or any member who } \\
\text { recently had sexual intercourse }\end{array}$ & Liberia & Mano & [48] \\
\hline R. vinifera & leaf & to ward off the evil & $\begin{array}{l}\text { fresh bud leaves are } \\
\text { suspended as a curtain in the } \\
\text { villages' entrances to ward off } \\
\text { the evil }\end{array}$ & & Cameroon & & $\begin{array}{l}\text { [van Andel, } \\
\text { unpublished] }\end{array}$ \\
\hline $\begin{array}{l}\text { Unidentified } \\
\text { palm }\end{array}$ & $\begin{array}{l}\text { seed (palm } \\
\text { nut) }\end{array}$ & oracles & $\begin{array}{l}\text { palm nuts used in Afa divination } \\
\text { in Benin. The } 16 \text { palm nuts were } \\
\text { cleared, marked with certain Afa } \\
\text { motif, and thrown from right } \\
\text { hand to the left to reveal the } \\
\text { destined combination }\end{array}$ & & Benin & & {$[50]$} \\
\hline
\end{tabular}


Table 1 Ritual uses of palms in traditional medicine in sub-Saharan Africa, including scientific plant names, plant parts used and detailed use description (Continued)

\begin{tabular}{|c|c|c|c|c|c|c|c|c|}
\hline $\begin{array}{l}\text { Unidentified } \\
\text { palm }\end{array}$ & $\begin{array}{l}\text { seed (palm } \\
\text { nut) }\end{array}$ & oracles & $\begin{array}{l}\text { palm nuts used in secret } F a \\
\text { divination in order to decrypt } \\
\text { and read the signature of god }\end{array}$ & & Benin & & {$[38]$} & \\
\hline $\begin{array}{l}\text { Unidentified } \\
\text { palm }\end{array}$ & $\begin{array}{l}\text { leaf (palm mat } \\
\text { made of leaf } \\
\text { fiber) }\end{array}$ & broken limbs/splints & $\begin{array}{l}\text { mats of split palm are tied } \\
\text { around with bark string. The } \\
\text { legs of chicken are broken to } \\
\text { cure the patient and the } \\
\text { chicken together }\end{array}$ & $\begin{array}{l}\text { the patient is segregated from } \\
\text { the village in a grass hut. } \\
\text { Medicine leaves are applied to } \\
\text { the skin under the mats. The legs } \\
\text { of chicken are broken to treat } \\
\text { the chicken and the patient } \\
\text { together. When the chicken } \\
\text { starts to walk again so will the } \\
\text { patient }\end{array}$ & Zambia & Lunda & {$[9]$} & \\
\hline $\begin{array}{l}\text { Unidentified } \\
\text { palm }\end{array}$ & $\begin{array}{l}\text { seed (palm } \\
\text { nut) }\end{array}$ & craw-craw & $\begin{array}{l}\text { leaves of Morinda morindoides } \\
\text { (Baker)Milne-Redh. (cited as } \\
\text { Morinda confusa) are mashed } \\
\text { and made into a leaf packet } \\
\text { with two palm nuts; the packet } \\
\text { is roasted in the fire }\end{array}$ & the pulp is rubbed on the skin & Liberia & Mano & [48] & $\begin{array}{l}\text { the author adds: "the nuts are } \\
\text { obviously magical" }\end{array}$ \\
\hline $\begin{array}{l}\text { Unidentified } \\
\text { palm }\end{array}$ & $\begin{array}{l}\text { seed (palm } \\
\text { nut) }\end{array}$ & pterygium & $\begin{array}{l}\text { a palm nut is carefully cracked } \\
\text { and the kernel removed entire; } \\
\text { a hole is bored through the } \\
\text { kernel; the operator chews up a } \\
\text { leaf of Microdesmis puberula } \\
\text { Hook.f., and holding the palm } \\
\text { kernel bead against the white } \\
\text { spot on the eye, blows the leaf } \\
\text { emulsion into it }\end{array}$ & $\begin{array}{l}\text { the leaf emulsion is blown into } \\
\text { the eye. If the lesion is recent it } \\
\text { will go away at once }\end{array}$ & Liberia & Mano & {$[48]$} & \\
\hline $\begin{array}{l}\text { Unidentified } \\
\text { palm }\end{array}$ & $\begin{array}{l}\text { seed (palm } \\
\text { kernel) }\end{array}$ & impotence & $\begin{array}{l}\text { young leaves of Microdesmis } \\
\text { puberula Hook.f. are chewed } \\
\text { with palm kernels, while the } \\
\text { mass is rubbed on the back of } \\
\text { the loins }\end{array}$ & see preparation & Liberia & Mano & {$[48]$} & \\
\hline $\begin{array}{l}\text { Unidentified } \\
\text { palm }\end{array}$ & $\begin{array}{l}\text { sap (palm } \\
\text { wine) }\end{array}$ & smallpox & $\begin{array}{l}\text { palm wine is an important } \\
\text { drink for patient, and offering to } \\
\text { the Shopanna god }\end{array}$ & $\begin{array}{l}\text { palm wine should be drunk and } \\
\text { sprinkled throughout the house } \\
\text { to appease Shopanna, but the } \\
\text { patient should also be rubbed } \\
\text { with it. Relatives should not sleep } \\
\text { near an infected person, nor visit } \\
\text { anyone outside. Roasted } \\
\text { groundnuts should not be eaten } \\
\text { during an epidemic, as this } \\
\text { would offend Shopanna. No } \\
\text { drumming should be performed }\end{array}$ & Nigeria & Yoruba & {$[47]$} & \\
\hline
\end{tabular}


Table 1 Ritual uses of palms in traditional medicine in sub-Saharan Africa, including scientific plant names, plant parts used and detailed use description

(Continued)

\begin{tabular}{|c|c|c|c|c|c|c|c|}
\hline \multicolumn{8}{|c|}{$\begin{array}{ll}\text { a small switch of Ixora sp. and a } & \text { a snake man rubs his finger in } \\
\text { bit of Vernonia conferta Benth are } & \text { medicine and licks it saying: "if } \\
\text { calcined and the powder is put in } & \text { anyone wants to make wi for } \\
\text { a small horn; palm wine is added } & \text { me, let him come to me } \\
& \text { straight" - meaning that if } \\
& \text { anyone wants to bewitch him } \\
& \text { will come foolishly like an } \\
& \text { intoxicated man and tell him } \\
& \text { what he has come for }\end{array}$} \\
\hline $\begin{array}{l}\text { Unidentified } \\
\text { palm }\end{array}$ & $\begin{array}{l}\text { sap (pam } \\
\text { wine) }\end{array}$ & black magic - poison & $\begin{array}{l}\text { a bark of a tree from Rutaceae } \\
\text { family is beaten and partially } \\
\text { dried, castings of earth worms } \\
\text { are added and all heated } \\
\text { thoroughly. While beating the } \\
\text { mixture the name of the victim } \\
\text { is called and the poison is told } \\
\text { to kill the victim in two days. A } \\
\text { thumb of the poison is placed } \\
\text { in a gourd of palm wine }\end{array}$ & $\begin{array}{l}\text { the victim is invited a gourd of } \\
\text { palm wine with a thumb of the } \\
\text { poison always using the left } \\
\text { hand }\end{array}$ & Liberia & Mano & [48] \\
\hline $\begin{array}{l}\text { Unidentified } \\
\text { palm }\end{array}$ & $\begin{array}{l}\text { sap (palm } \\
\text { wine) }\end{array}$ & $\begin{array}{l}\text { sacrifice to various } \\
\text { spirits to buy } \\
\text { protection }\end{array}$ & $\begin{array}{l}\text { a sacrifice (offering) made of } \\
\text { food, cotton, parts of a sacrificial } \\
\text { animal and palm wine }\end{array}$ & $\begin{array}{l}\text { accompanied by a prayer: "We } \\
\text { come to you. We want you to } \\
\text { come and eat with us. Here is } \\
\text { your part. This cotton is our } \\
\text { clothing and our money. This is } \\
\text { part of our meat. Here is some } \\
\text { palm wine for you. We want you } \\
\text { to help us. Bring us good luck, let } \\
\text { us have no sickness, let us have } \\
\text { plenty of money, let us have } \\
\text { good crops and plenty of } \\
\text { children. (...) Come and be a } \\
\text { god to us and do not let any evil } \\
\text { befall us" }\end{array}$ & Liberia & Mano & [48] \\
\hline $\begin{array}{l}\text { Unidentified } \\
\text { palm }\end{array}$ & $\begin{array}{l}\text { whole plant } \\
\text { (palm tree) }\end{array}$ & charm, selfprotection & $\begin{array}{l}\text { a self-protecting charm which } \\
\text { involves putting one's life into a } \\
\text { hiding place; and some people } \\
\text { are doctored to hide in a palm } \\
\text { tree. When such a one dies, the } \\
\text { palm falls; and should the palm } \\
\text { fall first (a very unlikely event), the } \\
\text { man would die }\end{array}$ & see preparation & Zambia & Ba-lla & {$[45]$} \\
\hline
\end{tabular}


Table 1 Ritual uses of palms in traditional medicine in sub-Saharan Africa, including scientific plant names, plant parts used and detailed use description (Continued)

\begin{tabular}{|c|c|c|c|c|c|c|c|}
\hline $\begin{array}{l}\text { Unidentified } \\
\text { palm }\end{array}$ & fruit & $\begin{array}{l}\text { prayer before } \\
\text { administratin } g \text { the } \\
\text { drug }\end{array}$ & $\begin{array}{l}\text { a doctor sits before the patient } \\
\text { and holds in one hand the } \\
\text { small calabash containing the } \\
\text { medicine, and in the other } \\
\text { takes a rattle made of round } \\
\text { palm fruit on a handle, and as } \\
\text { he rattles it he prays as follows: } \\
\text { "I am humble! It is thou who } \\
\text { created this medicine and all } \\
\text { things. May this person live. } \\
\text { Drive away witchcraft. Let this } \\
\text { medicine make him strong. May } \\
\text { he see life!" }\end{array}$ & see preparation & Zambia & Ba-lla & {$[45]$} \\
\hline $\begin{array}{l}\text { Unidentified } \\
\text { palm }\end{array}$ & $\begin{array}{l}\text { leaf (a string } \\
\text { made of palm } \\
\text { leaf) }\end{array}$ & $\begin{array}{l}\text { preventive against the } \\
\text { malign influence of } \\
\text { pregnant women }\end{array}$ & $\begin{array}{l}\text { a string made of palm leaf is } \\
\text { suspended on poles in front of } \\
\text { the hut to give warning, } \\
\text { especially to the pregnant } \\
\text { women. This is to "fend off by } \\
\text { means of string". If a pregnant } \\
\text { woman enters a hut where } \\
\text { there is a baby its skull would } \\
\text { part asunder }\end{array}$ & see preparation & Zambia & Ba-lla & {$[55]$} \\
\hline $\begin{array}{l}\text { Unidentified } \\
\text { palm }\end{array}$ & $\begin{array}{l}\text { whole plant } \\
\text { (palm tree) }\end{array}$ & $\begin{array}{l}\text { a sacred spot } \\
\text { associated with the } \\
\text { demigod }\end{array}$ & $\begin{array}{l}\text { a bare place about an acre in } \\
\text { extent, with a solitary palm-tree } \\
\text { growing upon it. It is reckoned } \\
\text { as "chikomo": a word applied to } \\
\text { places, rites, and customs } \\
\text { traditionally associated with } \\
\text { demigods. It is there that the } \\
\text { communal gatherings take } \\
\text { place before and after war: e.g. } \\
\text { where the warriors are doctored }\end{array}$ & see preparation & Zambia & Ba-lla & {$[55]$} \\
\hline $\begin{array}{l}\text { Unidentified } \\
\text { palm }\end{array}$ & leaf & $\begin{array}{l}\text { protective amulet - } \\
\text { against the } \\
\text { perspiration of those } \\
\text { who have sexual } \\
\text { relations }\end{array}$ & $\begin{array}{l}\text { convalescents after a disease } \\
\text { are provided with fowa- a rattle } \\
\text { which consists of a root } \\
\text { (unknown plant) contained in a } \\
\text { kind of round box made of } \\
\text { palm leaf }\end{array}$ & tied around the ankle & $\begin{array}{l}\text { South } \\
\text { Africa }\end{array}$ & Thonga & [10] \\
\hline $\begin{array}{l}\text { Unidentified } \\
\text { palm }\end{array}$ & leaf & $\begin{array}{l}\text { possession by spirits - } \\
\text { madness }\end{array}$ & & $\begin{array}{l}\text { a large palm leaf from Milala } \\
\text { palm is waved in front of a } \\
\text { patient - sufficient to "scatter } \\
\text { the spirits" which cause } \\
\text { madness }\end{array}$ & $\begin{array}{l}\text { South } \\
\text { Africa }\end{array}$ & Thonga & [10] \\
\hline
\end{tabular}


Table 1 Ritual uses of palms in traditional medicine in sub-Saharan Africa, including scientific plant names, plant parts used and detailed use description

\section{(Continued)}

\begin{tabular}{|c|c|c|c|c|c|c|c|}
\hline $\begin{array}{l}\text { Unidentified } \\
\text { palm }\end{array}$ & $\begin{array}{l}\text { sap (palm } \\
\text { wine) }\end{array}$ & $\begin{array}{l}\text { preventive/offering/ } \\
\text { sacrifice }\end{array}$ & $\begin{array}{l}\text { palm wine in a big pot called } \\
\text { gandjelo (which also means altar) } \\
\text { is an offering for ancestor-gods. } \\
\text { This is necessary to obtain the } \\
\text { favor and help of the ancestor- } \\
\text { gods; or to reduce their anger } \\
\text { and, therefore, the risk of disease } \\
\text { or other calamity brought by } \\
\text { displeased ancestor-gods }\end{array}$ & see preparation & $\begin{array}{l}\text { South } \\
\text { Africa }\end{array}$ & Thonga & {$[10]$} \\
\hline $\begin{array}{l}\text { Unidentified } \\
\text { palm }\end{array}$ & leaf & $\begin{array}{l}\text { punishment of } \\
\text { thieves }\end{array}$ & $\begin{array}{l}\text { a person which is guilty of having } \\
\text { stolen the missing property may } \\
\text { be punished by confrontation } \\
\text { with several palm leaves, which, } \\
\text { by a kind of supernatural } \\
\text { judgment, turn into snakes }\end{array}$ & see preparation & $\begin{array}{l}\text { South } \\
\text { Africa }\end{array}$ & Thonga & {$[10]$} \\
\hline $\begin{array}{l}\text { Unidetified } \\
\text { palm }\end{array}$ & leaf & $\begin{array}{l}\text { "when it bites inside" } \\
\text { - colic }\end{array}$ & $\begin{array}{l}\text { the remedy is prepared from } \\
\text { the roots of unknown plants, } \\
\text { cut into equal lengths and tied } \\
\text { together with a band of palm } \\
\text { leaf (a bunch is called } \\
\text { shitsimbo). The bunch is then } \\
\text { boiled to bring out the active } \\
\text { principles of the drug }\end{array}$ & $\begin{array}{l}\text { the decoction is taken by a } \\
\text { patient just as it is; sometimes it } \\
\text { is mixed with maize. The bunch } \\
\text { retains medicinal properties for } \\
\text { a long time and it may be used } \\
\text { during a whole week }\end{array}$ & $\begin{array}{l}\text { South } \\
\text { Africa }\end{array}$ & Thonga & {$[10]$} \\
\hline $\begin{array}{l}\text { Unidetified } \\
\text { palm }\end{array}$ & leaf & festivities & palm skirts used by dancers & & Liberia & Poro & {$[48]$} \\
\hline $\begin{array}{l}\text { Unidetified } \\
\text { palm }\end{array}$ & leaf & festivities & palm skirt used by women & & Zambia & Mwila & [45] \\
\hline $\begin{array}{l}\text { Unidetified } \\
\text { palm }\end{array}$ & leaf & vodun & $\begin{array}{l}\text { a vodun Vo-sisa used to be } \\
\text { placed opposite to the house } \\
\text { gates to defend the inhabitants } \\
\text { from harm. It usually consisted } \\
\text { of a pole, with an empty old } \\
\text { calabash for a head, and a body } \\
\text { composed of grass thatch, palm } \\
\text { leaves, fowl's feathers, and } \\
\text { snails' shells }\end{array}$ & & Benin & & {$[50]$} \\
\hline $\begin{array}{l}\text { Unidetified } \\
\text { palm }\end{array}$ & leaf & sacrifice & $\begin{array}{l}\text { palm fronds are used in kudio, } \\
\text { which are sacrifices used to heal } \\
\text { a dying person by exchanging } \\
\text { the life of an animal for that of } \\
\text { the person }\end{array}$ & & Benin & & [37] \\
\hline \multirow[t]{2}{*}{$\begin{array}{l}\text { Unidetified } \\
\text { palm }\end{array}$} & leaf & offerings & $\begin{array}{l}\text { offerings are made to various } \\
\text { vodun spirits over a fresh bed of } \\
\text { azan - ritual palm fronds which } \\
\text { mark the sacred spot }\end{array}$ & & Benin & & {$[37]$} \\
\hline & leaf & protective & & & Benin & & [50] \\
\hline
\end{tabular}


Table 1 Ritual uses of palms in traditional medicine in sub-Saharan Africa, including scientific plant names, plant parts used and detailed use description (Continued)

\begin{tabular}{|c|c|c|c|c|c|}
\hline $\begin{array}{l}\text { Unidetified } \\
\text { palm }\end{array}$ & & & $\begin{array}{l}\text { the azan (ritual palm fronds) } \\
\text { was worn around the throat, to } \\
\text { protect from witchcraft or from } \\
\text { being killed during war }\end{array}$ & & \\
\hline $\begin{array}{l}\text { Unidetified } \\
\text { palm }\end{array}$ & leaf & punishment & $\begin{array}{l}\text { palm fronds are carried by } \\
\text { people involved in punishing } \\
\text { social deviants, and those } \\
\text { suspected of witchcraft }\end{array}$ & Benin & [38] \\
\hline $\begin{array}{l}\text { Unidetified } \\
\text { palm }\end{array}$ & leaf & punishment & $\begin{array}{l}\text { during the 'witch parades } \\
\text { 'organized to punish and march } \\
\text { the accused Beninese women } \\
\text { to prison, the witches are } \\
\text { bedecked in wreaths of palm } \\
\text { fronds }\end{array}$ & Benin & [39] \\
\hline $\begin{array}{l}\text { Unidetified } \\
\text { palm }\end{array}$ & $\begin{array}{l}\text { sap (palm } \\
\text { wine) }\end{array}$ & offering & $\begin{array}{l}\text { sodabi which is a locally } \\
\text { distilled palm wine is used in } \\
\text { offerings made to vodun spirit } \\
\text { called Tchamba - an old spirit } \\
\text { based on domestic African } \\
\text { enslavement }\end{array}$ & Benin & [63] \\
\hline
\end{tabular}


Table 2 Ritual uses of palms in sub-Saharan Africa

\begin{tabular}{|c|c|c|}
\hline Palm species & Palm part(s) used & Purpose \\
\hline \multirow[t]{2}{*}{ Borassus aethiopum Mart. African fan palm } & \multirow[t]{2}{*}{ seed, root } & - treatment of diseases and disorders \\
\hline & & - ceremonies \\
\hline \multirow[t]{3}{*}{ Cocos nucifera L. Coconut } & \multirow[t]{3}{*}{ fruit, entire palm tree } & - treatment of diseases and disorders \\
\hline & & - sacred places \\
\hline & & - offerings \\
\hline Dypsis canaliculata Jum. (Beentje) \& J.Dransf. & entire palm tree & - sacred places \\
\hline Dypsis fibrosa (C.H.Wright) Beentje \& J.Dransf. & leaf & - ceremonies \\
\hline Dypsis pinnatifrons Mart. & leaf & - ceremonies \\
\hline \multirow[t]{5}{*}{ Elaeis guinnensis Jacq. African oil palm } & \multirow{5}{*}{$\begin{array}{l}\text { fruit, seed, infructescence/inflorescence, } \\
\text { leaf, root }\end{array}$} & - treatment of diseases and disorders \\
\hline & & - offerings \\
\hline & & - protection \\
\hline & & - oracles \\
\hline & & - taboo \\
\hline Elaeis guineensis var. idolatrica A.Chev. & entire palm tree & - sacred places \\
\hline \multirow[t]{2}{*}{ Hyphaene coriacea Gaertn. Doum palm } & \multirow[t]{2}{*}{ leaf } & - treatment of diseases and disorders \\
\hline & & - ceremonies \\
\hline Hyphaene petersiana Klotzsch ex Mart. & leaf & - ceremonies \\
\hline Phoenix reclinata Jacq. Senegal date palm & leaf & - ceremonies \\
\hline Raphia farinifera (Gaertn.) Hyl. & leaf & - ceremonies \\
\hline Raphia hookeri G.Mann \& H.Wendl. Raphia-palm & seed & - treatment of diseases and disorders \\
\hline Raphia vinifera P.Beauv. West African piassava palm, Bamboo-palm & leaf & - protection \\
\hline \multirow[t]{5}{*}{ Unidentified palm species } & \multirow[t]{5}{*}{ leaf } & - treatment of diseases and disorders \\
\hline & & - offerings \\
\hline & & - protection \\
\hline & & - oracles \\
\hline & & - ceremonies \\
\hline
\end{tabular}

The purposes are generalized into categories.

On Mfangano Island in Kenya, the Suba and Luo still use the fruits of Cocos nucifera to alleviate skin rash associated with HIV/AIDS. The disease - locally known as 'chira', and its etiology is related to the transgression of principles governing sexuality or seniority. These include adultery committed during a wife's pregnancy, having sexual intercourse during the harvest, or failure to observe the proper separation of sexuality between generations [46].

Disorders of the reproductive system that fail to respond to rational therapy are often explained by witchcraft or broken taboos $[7,47]$. In Nigeria, to prevent miscarriage Yoruba people used to roast a tortoise with coconut water and half a bottle of palm oil from Elaeis guineensis, after which the mixture was ground to powder [47]. The powder was consumed in a corn flour pudding, taken every morning and evening during one menstrual period, followed by sexual intercourse five days after finishing menstruating. The Yoruba saw the tortoise as a symbol for a prostitute, which might signify that when a woman suffered miscarriage it could be due to committed adultery or a broken taboo [47]. Sex taboos in particular were often used as an explanation for the occurrence of a disease [45,48]. For the treatment of malaria, the Yoruba used start the ritual with two rings painted on the neck, one with shea butter (Vitellaria paradoxa), and another with Elaies guineensis oil [47].

In Liberia, the Mano used red palm oil in treatments of mysterious diseases. To awake a patient in coma, red palm oil was mixed with a burned knot of the parasite Loranthus micranthus and rubbed on the patient's cheeks toward the mouth in order to make him talk (all information in this paragraph derived from [48]). Another magical medicine was prepared from any branch broken off by wind but lodged before it reached the ground, mixed with some burned plants and Elaeis guineensis oil. The paste was put into a little horn tied to a cut off cow's tail. The traditional healer asked the sick man a question while brushing his face with the tail. If there was no answer, 


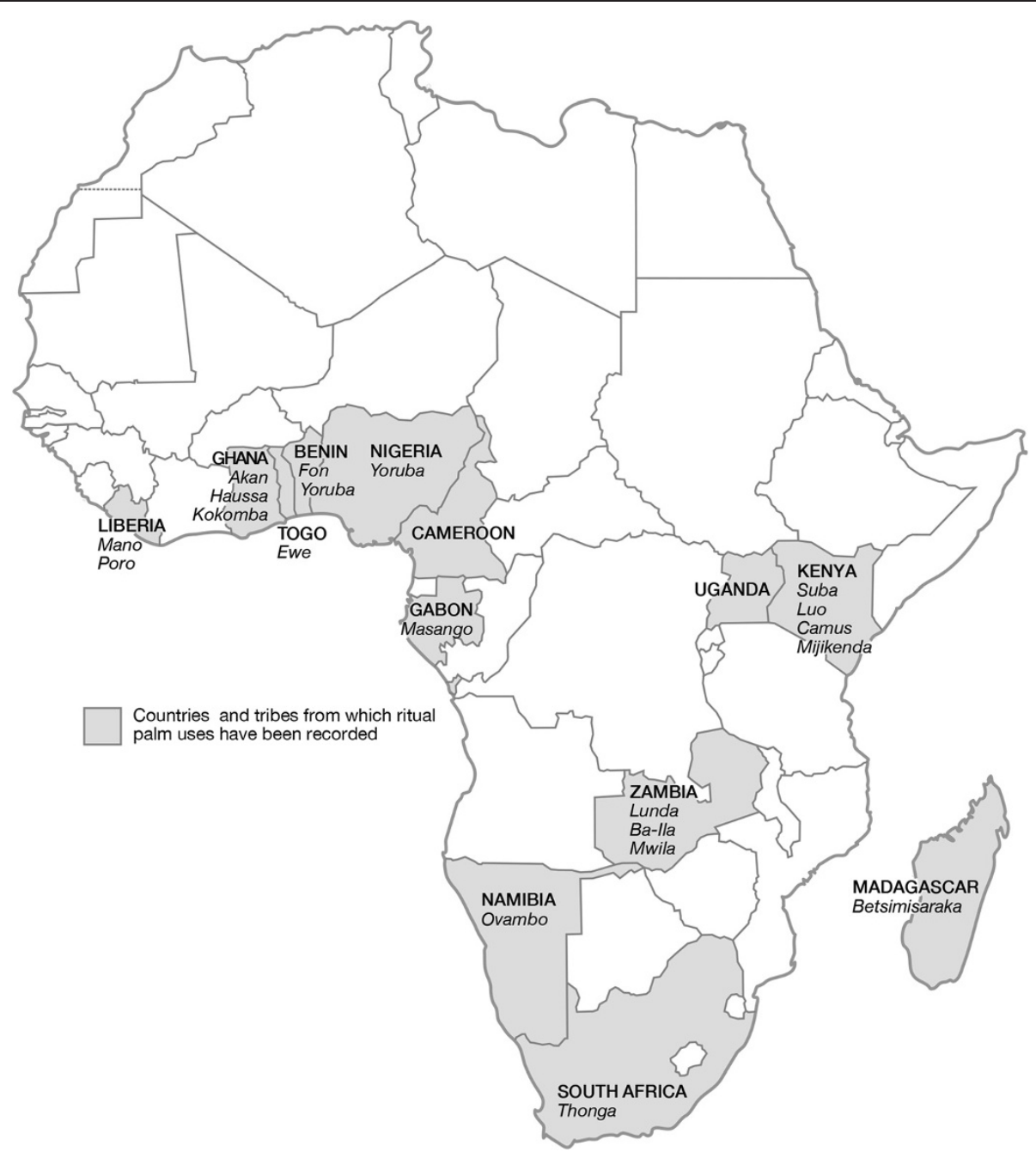

Figure 1 Localities in sub-Saharan Africa where ritual uses of palms have been reported. In total 81 ritual uses of at least 12 palm species have been reported in 13 countries and 19 ethnic groups.

it meant that the patient would die. If he answered, the healer took some medicine with his left third finger, and rubbed it over the patient's heart while saying specific prayers. The broken but not fallen branch perhaps symbolized hope for the patient to wake up. The palm oil was used to blend the various added ingredients. Similar symbols appeared when healing fractures in Liberia. A few branches from various shrubs and trees were gathered, together with any broken twig which was healed but growing in a twisted position. The charred wood was mixed with red palm oil, and the ointment was then applied to the fracture. The twisted branch probably symbolized the twisted limb. Another example of sympathetic magic among the Mano was a cure for acute hepatitis, in which shelf fungi shaped like a liver were mixed with Elaeis guineensis oil and rubbed over the liver. In a cure for palpitation, the Mano mixed red palm oil with an inflorescence of
Costus sp. and a handful of buds from Harungana madagascariensis. Part of the mixture was put in an iron spoon with four pebbles that had been heated in the fire. There would be three pebbles used if the patient was a female. Notably, the stone represented longevity and strength, and the red color of palm oil as well as the red sap from $H$. madagascariensis probably symbolized the color of the treated heart. Gender specific symbolic medicines were also used in Liberia for rheumatism due to yaws. Enchanted elements were the leaves and bark of living plants and red palm oil, which represented the active male elements. The charred plants and "burned" oil represented the soothed, magical, more preventive female elements. Male and female medicines were mixed in order to form even more powerful Mano medicine, and possibly to achieve an ideal balance between active and controlled features of persons and situations. Women in Liberia used to protect themselves from getting sick during the 
meetings of the Ba Kona snake society using a medicine horn made of charred twig of Protomegabaria stapfiana and red palm oil. The medicine was tied to the woman's waist and licked from the finger whenever she felt dizzy or afraid. Although in many ritual medicines palm oils served merely as a rubbing agent, the use of the oil could also be a taboo. In Liberian Sukba Society it was forbidden to put red E. guineensis oil into a horn of medicine, which was a fetish prepared to protect from witchcraft. If the taboo was broken, the fetish could turn against its owner; catch him and kill him instead of the witch [48].

In Gabon, the Masango used the leaves of Hyptis lanceolata mixed with palm oil to apply on the body as medico-magic [49]. Palm oil is still offered to a variety of vodun spirits in Benin [37]. For the annual yam celebration, the guardian spirit Legba receives yams, palm oil, chicken blood, and other offerings. Throughout coastal Benin, palm oil is also used in $v o$, which are sacrifices or offerings used in daily problem solving. An example of vo is a calabash containing kola nuts, palm oil, and other items indicated by the diviner. It is placed in the center of a paved road, and by end of the day it is run over by cars, so the problems are destroyed [37]. In Benin near almost every door there used to stand the Legba-pot, filled every morning and evening with cooked maize and palm oil [50]. For another vodun called the "Vulture's Dish", passers-by used to deposit a little food or palm oil, to bring luck or ward off danger [50].

\section{Seed}

In Liberia, palm kernel oil was applied with owl's feathers on wounds resulting from scarification performed during the Poro initiation rites [48]. In Cameroon, fresh seeds of Elaeis guineensis were mashed and mixed with other plants to treat mental fatigue. The residues of medicine were put under the pillow, and only if the patient dreamed of a young girl with erected breasts, there was hope for cure [51]. Elaeis guineensis seeds were also used as sacred objects in rituals involved in oracles, which helped to discover the cause of disease or other calamities for example the Afan oracle of the Ewe in Togo, or the Ifa oracle of the Yorubas and $\mathrm{Fa}$ oracle of the Fon in Benin [51]. In the Afa divination in Benin, 16 palm nuts were cleared, marked with certain Afa motif, and thrown from right hand to the left to reveal the destined combination [50]. In 1990s palm nuts were still used in Benin in secret Fa divination in order to decrypt and read the signature of $\mathrm{Fa}$ - a god of oracles [38].

Craw-craw, is the local term for onchocerciasis or river blindness, which causes itchy rashes and nodular swellings on the skin. In Liberia crawcraw was threated with mashed leaves of the brimstone tree Morinda lucida made into a leaf packet with two palm seeds. The packet was roasted in the fire and the pulp rubbed on the skin.
According to Harley [48], p. 92 "The nuts obviously are magical". Among the Mano in Liberia, impotence, which was widely believed to be caused by witchcraft, used to be treated with palm seeds chewed with young leaves of Microdesmis puberula, and the mass was then rubbed on the genitals [48]. The presence of M. puberula in the treatment for impotence might be linked to its wood which is very hard [52].

In Ghana, hollowed out Borassus aethiopum seeds are still used by Haussa's as containers for a charred medicinal mixture called 'katala' in Haussa. This mixture is rubbed into skin incisions during scarification practices [11].

The seeds of Raphia hookeri were sold in 2010 and 2011 on markets in Ghana and Benin to treat a baby's fontanel when it "beats", which is seen as an unhealthy symptom $[11,53]$. The seeds are roasted over the fire until they are black as coal, ground to powder, mixed with oil and the mixture is smeared on the fontanel. The seeds are also boiled as tea or added to herbal baths to treat babies with beating fontanels [54].

\section{Inflorescence/infructescence}

In Ghana, empty infructescences of Elaeis guineensis alone or mixed with ginger (Zingiber officinale) are burned and applied as magical medicine in the form of an enema to small children to encourage them to walk at an early age [van Andel, unpublished]. Also in Ghana, the Akan burn inflorescences from Elaeis guineensis so the smoke drives away bad spirits $[7,11]$.

\section{Leaves}

In Zambia splints made of palm mats used to be tied around broken limbs with bark strips, and medicine was applied on the skin under the mats [9]. Simultaneously, the legs of a chicken were broken and treated with the same medication. The Lundas believed that when the chicken starts to walk again, so will the patient. Palm leaves were used as protective barriers by the Ba-Ila. A string made of fibers extracted from the palm leaf was suspended on poles in front of the hut to warn pregnant women. If a pregnant woman entered a hut where there was a baby, its skull would part into pieces $[45,55]$.

During secret meetings of the Mano in Liberia, a curtain of young Raphia vinifera leaves protected from any outsider who could perform witchcraft, bring poison, or any person who recently had sexual intercourse [48].

In Cameroon, fresh bud leaves of Raphia vinifera are still suspended as a curtain in the villages' entrances to ward off the evil [van Andel, unpublished].

In Benin a vodun Vo-sisa used to be placed opposite to the house gates to defend the inhabitants from harm. It usually consisted of a pole, with an empty old calabash for a head, and a body composed of grass thatch, palm leaves, fowl's feathers, and snails' shells [50]. 
Palms were also used as protective amulets. In Benin and Togo, ill people carried twigs of Elaeis guineensis around the neck or arm to achieve invulnerability [51].

In South Africa, during the hondlola purification ceremony, performed after a cure was accomplished, the Thonga protected themselves from perspiration of those who had sexual relations. A convalescent was provided with fowa, which was a kind of round rattle made of palm leaf tied around the ankle. Madness, which the Thonga associated with spirit possession, was treated by waving a large palm leaf from the milala palm (most probably Hyphaene coriacea) in front of the patient, which would "scatter the spirits". Also "when it bites inside" a medicine was prepared from various equally cut roots that were tied together with a band of palm leaf, and boiled to bring out the active principles of the drug [10].

Palm fronds are still used in Benin in kudio, which are sacrifices used to heal a dying person by exchanging the life of an animal for that of the person [37]. Also, offerings are made to various vodun spirits over a fresh bed of azan ritual palm fronds which mark the sacred spot [37]. The azan was also worn around the throat, to protect from witchcraft or from being killed during war [50]. In Benin, palm fronds are also carried by people involved in punishing social deviants, and those suspected of witchcraft [38]. During the recent 'witch parades' organized to punish and march the accused Beninese women to prison, the witches were bedecked in wreaths of palm fronds [39]. Perhaps palms bring justice because they are associated with understanding, peace, and harmony, or with indwelling tree spirits themselves [56]. In South Africa a thief was punished by confrontation with palm leaves, which, by a kind of supernatural judgment, turned into snakes [10].

Palm leaves also served in various ceremonies, rituals and religious festivities. In Kenya, the Camus tied the leaves of Hyphaene coriacea to boys' legs and heads of women during the circumcision ceremony [57]. Skirts made from palm leaves were used by the masked Poro dancers, and by the Mwila women on festive occasions [45,48]. Leaves of Hyphaene petersiana were used in Namibia to prepare bridal hats among the Ovambo [58]. Nowadays, in Uganda, leaves of Phoenix reclinata are used for ceremonial and religious purposes [59]. Betsimisaraka people of Madagascar use leaves of Dypsis pinnatifrons in decoration of churches. Leaves of Raphia farinifera are used for making crosses, and they are burned as incense at the church [12]. Entire leaves of Dypsis fibrosa are used by the Betsimisaraka to decorate houses at clerical festivities [14]. Carrying the palm fronds on Palm Sunday is an important Christian tradition practiced now in many parts of Africa [60,61].

\section{Sap (palm wine)}

In Nigeria, to recover from smallpox, palm wine was drunk and rubbed on the body of the patient. Relatives were advised not to sleep near an infected person, nor visit anyone outside. Roasted groundnuts (Arachis hypogaea) were not to be eaten during an epidemic, and no drumming could be performed. These activities would offend the Shopanna god who, according to Yoruba beliefs, was responsible for bringing smallpox epidemics upon mankind. For successful recovery it was also necessary to make an offering to the Shopanna god by sprinkling palm wine all over the house to appease the god [47]. Ancestor spirits appreciate drinks, and palm wine was often used in offerings and fetishes to obtain their favor and help or to reduce their anger and, therefore, the risk of disease or other calamity $[10,48]$. To engage a powerful being in a relationship of beneficial exchange and prosperity, palm wine was a valued consumable and lubricant of good relations and hospitality. In Kenya, Mijikenda people used to place the coconut shells filled with palm wine on ancestors' graves as an offering [62]. In Benin, sodabi which is a locally distilled palm wine is still used in offerings made to vodun spirit called Tchamba - an old spirit based on domestic African enslavement [63].

The Mano of Liberia carried amulets for protection against witchcraft, made from small horns with enclosed palm wine and charred and powdered twig of Ixora sp. and Vernonia conferta. By licking the medicine from the finger, a person was ensured that if anyone wanted to bewitch him, he would foolishly turn himself out, and would subsequently be called to account [48]. Although most medicines were directed toward the cure and prevention of disease, some could also embrace poisons [5,9,10,64]. In Liberia, a poisonous mixture was prepared while calling the name of the victim, put under the thumbnail and then placed in a gourd of palm wine. The victim was offered the lethal drink, always using the left hand [48].

\section{Root}

Ritual uses of roots are few. Roots of Elaeis guineensis in mixture with the resin from Daniellia oliveri and Commiphora africana were reported to keep away bad spirits in West Africa [51].

In Ghana, a decoction from Borassus aethiopum roots is still used by Kokomba traditional healers in the treatment of any disease caused by a curse [Gruca, unpublished]. In Togo, macerated roots from B. aethiopium are used in herbal baths, and powdered or decocted roots from $E$. guineensis are used orally to treat epilepsy [65]. It is believed that epilepsy occurs mostly during the full moon. Mysterious and spontaneous diseases such as epileptic seizures are often associated with supernatural forces [66].

\section{Entire palm tree}

Palm trees played a protective role in Zambia. According to Ba-Ila beliefs, a person could be guarded from harm 
during the entire life by hiding one's life in a palm tree. This protective ritual ensured that only if the palm tree would fall the person would die, and since this event was considered unlikely, a palm tree was a safe place to hide one's life [45]. That might be because the palm tree, due to its unchanging beauty of the evergreen foliage, is considered a symbol of everlasting life, permanence and strength [67]. In Zambia, solitary growing palm trees also provided sacred places where rites and customs traditionally associated with half-gods were performed [55].

The French botanist Chevalier [68] published a varietal name of the African oil palm (Elaeis guineensis var. idolatrica) referring to its divine characters. Current taxonomy treats this name as a synonym of E. guineensis [42] but it is still mentioned as the "idolatrica" palm in some literature even if it cannot be recognized taxonomically. In Benin, the "idolatrica" palm has been recently reported as sacred and protected where ever it grows because it is seen as the realization on earth of the god $F a$. Nobody is allowed to cut it down or to use its fruits for making oil. The ritual use of these palms is reserved for soothsayers called bokonon [69].

In Madagascar Cocos nucifera and Dypsis canaliculata are still planted at sacred places by the Betsimisaraka people [13]. The Wanaka of East Africa believed that the coconut palm has a spirit, and destruction of this tree is equivalent to matricide because the coconut tree gives people nourishment, as a mother nourishes her child [56].

\section{Discussion}

At least 12 palm species were found to be involved in various ritual practices (Table 2). Assuming that palm oil or red palm oil always come from Elaeis guineensis, this was the most commonly documented palm species for ritual purposes in Africa (see Table 1). Because several ritual uses of palms listed in the literature could not be unequivocally referred to a particular species, the picture we draw remains somewhat incomplete with regards to the taxonomic basis for ritual palm uses.

All parts of the palms were used in rituals, but the most commonly used part was the leaf, followed by the fruit and oil extracted from the fruit mesocarp, seed (and extracted palm kernel oil), entire palm tree, sap in the form of palm wine, root, inflorescence and infructescence. The ritual uses of all the mentioned parts were found in both older and recent literature, although most of the recent ritual use records were associated with the palm leaf.

In general, the ritual uses of palms play a double role. In some treatments, the palm is the actual sacred object or the central element of ritual practices, for example entire palm trees determine sacred places, palm seeds accompany oracles and palm leaves serve in offerings. In other cases, palms are used in mixtures with other plants or products. Hence, palms are not the primary ingredient, but support the ritual treatments in some way, like in the case of palm oil, used as a medium to blend and make coherent the various ingredients. It is noteworthy that palm wine and palm oil, which are commonly consumed in Africa, often assist the treatment and the contact with the supernatural world.

Our review shows that palms have been, and probably still are pervasive in African medicinal systems. Their use in medicines reflects the spiritual framework of traditional medical practices, and palms themselves are important and often crucial in disease treatment and prevention. Palm-derived medicines work not only upon diseases of the body, but also directly upon people's psyche and emotions. Palm medicines can act from a distance if so directed by the power of the spoken word. Sometimes taboos must be respected to secure efficacy. Ritual practices merge in all sorts of combinations with palm remedies. There is no assurance that any particular palm used for the treatment of a particular disease has any biologically active component; it may only be its symbolic or spiritual meaning that serves as a powerful ingredient. Some medicinal plants, just like placebo, can be efficacious without biologically active components [70].

The few studies we reviewed that explained the ritual uses of palms in detail were classic anthropological works that embraced studies of the entire native African tribes and cultures e.g. [5,9,10,45,47,48,55]. The best accounts of traditional medical practices came from those who spent years among the local people, not only observing but also sharing their everyday life. Many of the palm uses mentioned in our review came from these sources, but in many cases we do not know whether the cited rituals are still practiced today, as recent studies on African ritual plants are scarce.

One of the obstacles of ethnomedicinal studies is that little attempt is made to show a more comprehensive meaning of illness, which follows the use of alternative diagnoses and therapies in traditional medical practices. Disease episodes are usually presented only briefly and unambiguously disregarding socially important outcomes that may underlie it. Therefore, it is difficult to get an idea of what, from an emic medical point of view, is going on [71].

It is necessary to remember that the belief systems, which have developed over many generations, form the background to African medical treatments. Continuous interactions with the spiritual world are axiomatically absorbed in childhood, and subsequently reinforced in every phase of life. In fact, it is fascinating that ritual uses of palms are not only present in medicinal practices but in many other events practiced since time immemorial until today.

Knowledge of medicinal plants combined with spirituality continues to thrive in Africa today [31]. Some recent ethnobotanical field studies confirm that divination still plays a major role in the traditional knowledge systems, 
and palms are still used for this purpose just as they were many years ago [38,51,72]. The belief in witchcraft, divination and spiritual healing has come to coexist with Christianity, independence and development [65,73-76]. While in Cameroon palm fronds are carried by Christians on Palm Sunday [60], they are also used to ward off the evil in village entrances [van Andel, unpublished]. Palms are still considered sacred objects, assuring protection from malevolent forces $[37,38,63,69]$.

\section{Conclusions}

Palms are used in various prescriptions which include a ritual ingredient or procedure. It is impossible to understand the meaning and use of palms in African healing without seeing these uses as part of overall cultural systems, in which techniques of healing cannot be limited to bio-physical ailments or ideas of intervention. In local terms, food and medicine is not strictly separated, and palm products operate in many ways that cannot be isolated from the larger ensembles of elements and practices of which they are part. Effort must be made to provide meticulous reports on traditional remedies, as the enduring value of African medicines lies not only in the materials used, but also in the methods and the concepts underlying them.

\section{Competing interests}

The authors declare that they have no competing interests.

\section{Authors' contributions}

This study is part of MG's PhD study under supervision of HB. MG collected the data and wrote the first draft of the manuscripts which was subsequently edited and modified in several rounds by HB; TVA has contributed content and form to the later versions of the manuscript. All authors read and approved the final manuscript.

\section{Acknowledgments}

We thank professor Gustavo Romero, who supported and hosted MG's visit to Harvard University and made many resources available; and professor Jean Comaroff for her valuable comments and inspiration for writing this paper.

\section{Author details}

'Department of Bioscience - Research Group Ecoinformatics and Biodiversity, Aarhus University, Build. 1540, Ny Munkegade 114, DK-8000 Aarhus C, Denmark. ${ }^{2}$ Naturalis Biodiversity Center, Leiden University, P.O. Box 95172300 RA Leiden, the Netherlands.

Received: 3 February 2014 Accepted: 14 June 2014

Published: 23 July 2014

\section{References}

1. Mafimisebi TE, Oguntade AE: Preparation and use of plant medicines for farmers' health in Southwest Nigeria: socio-cultural, magico-religious and economic aspects. J Ethnobiol Ethnomed 2010, 6:1

2. Sofowora A: Medicinal Plants and Traditional Medicine in Africa. Ibadan, Nigeria: Spectrum Books; 1993.

3. Cocks M, Møller V: Use of indigenous and indigenised medicines to enhance personal well-being: a South African case study. Soc Sci Med 2002, 54(3):387-397.

4. Dagher D, Ross E: Approaches of South African traditional healers regarding the treatment of cleft lip and palate. Cleft Palate-Cran J 2004, 41(4):461-469.
5. Evans-Pritchard E: Witchraft, Oracles, and Magic among the Azande. (Ed. Eva Gillies). Oxford: Oxford University Press; 1976

6. Mill JE: I'm not a "basabasa" woman: an explanatory model of HIV illness in Ghanaian women. Clin Nurs Res 2001, 10(3):254-274.

7. Myren B: Magic in Southern Ghana, BSC thesis. Leiden: Department of Anthropology, Leiden University; 2011.

8. Stekelenburg J, Jager BE, Kolk PR, Westen EHMN, ven der Kwaak A, Wolffers IN: Health care seeking behavior and utilization of traditional healers in Kalaboo, Zambia. Health policy 2005, 71:67-81.

9. Turner V: Lunda medicine and the treatment of disease. In The Forest of Symbols: Aspects of Ndembu ritual. Edited by Turner V. USA: Cornell University Press; 1967:299-358.

10. Junod HA: The Life of a South African Tribe. Vol. II. 2nd edition. London: Macmillan and Co; 1927.

11. van Andel T, Myren B, van Onselen S: Ghana's herbal market. J Ethnopharmaco 2012, 14:368-378.

12. Burkill HM: The useful plants of West Tropical Africa. 2 Vol. 4th edition. Kew, London: Families M-R. Royal Botanic Gardens; 1997:340-392.

13. Byg A, Balslev H: Diversity and use of palms in Zahamena, eastern Madagascar. Biodivers Conserv 2001, 10:951-970

14. Byg A, Balslev H: Traditional knowledge of Dypsis fibrosa (Arecaceae) in Eastern Madagascar. Econ Bot 2001, 55(2):263-275.

15. Lee R, Balick MJ: Palms, people, and health. Ethnomedicine. Explore 2008 , 4(1):59-62.

16. Macía MJ, Armesilla PJ, Cámara-Leret R, Paniagua-Zambrana N, Villalba S, Balslev H, Pardo-de-Santayana M: Palm uses in northwestern South America: a quantitative review. Bot Rev 2011, 77:462-570.

17. Bellomaria B, Kacou P: Plantes et medicine populaire d'Agboville (Côte d'Ivoire). Fitoterapia 1995, 66:117-141.

18. Betti JL: An ethnobotanical study of medicinal plants among the baka pygmies in the Dja biospehere reserve, Cameroon. Afr Stud Monog 2004, 25(1):1-27.

19. El-Kamali HH, Khalid SA: The most common herbal remedies in Dongola Province, Northern Sudan. Fitoterapia 1998, 69:118-121.

20. Nadembega P, Boussim JI, Nikiema JB, Poli F, Antognoni F: Medicinal plants in Baskoure, Kourittenga Province, Burkina Faso: An ethnobotanical study. J Ethnopharmacol 2011, 133:378-395.

21. Zambrana NYP, Byg A, Svenning J-C, Moraes M, Grandez C, Balslev H: Diversity of palm uses in the western Amazon. Biodivers Conserv 2007, 16:2771-2778.

22. Bouton L: Palmeæ. In Plantes Médicinales de Maurice. 2nd edition. Mauritius: Port Louis Ile Maurice; 1864:133-134.

23. Le Clerk J: Des Plantes Médicinales de líle de la Réunion et de Leur Application a la Thérapeutique. France: Imprimerie du journal La Malle, Saint-Denis; 1864:46.

24. Yetein MH, Houessou LG, Lougbégnon TO, Teka O, Tente B: Ethnobotanical study of medicinal plants used for the treatment of malaria in plateau of Allada, Benin (West Africa). J Ethnopharmacol 2013, 146:154-163.

25. Allabi AC, Busiac K, Ekanmiana V, Bakionob F: The use of medicinal plants in self-care in the Agonlin region of Benin. J Ethnopharmacol 2011, 133:234-243.

26. Diallo D, Sogn C, Samaké FB, Paulsen BS, Michaelsen TE, Keita A: Wound healing plants in Mali, the Bamako Region. An ethnobotanical survey and complement fixation of water extracts from selected plants. Pharm Biol 2002, 40(02):117-128.

27. Dibong SD, Mpondo Mpondo E, Ngoye A, Priso RJ: Modalities of exploitation of medicinal plants in Douala's region. Am J Food Nutr 2011, 1(2):67-73.

28. Karou SD, Tchacondo T, Tchibozo MAD, Abdoul-Rahaman S, Anani K, Koudouvo K, Batawila K, Agbonon A, Simpore J, de Souza C: Ethnobotanical study of medicinal plants used in the management of diabetes mellitus and hypertension in the Central Region of Togo. Pharm Biol 2011, 49(12):1286-1297.

29. Matavele J, Habib M: Ethnobotany in Cabo Delgado, Mozambique: use of medicinal plants. Environ Dev Sustain 2000, 2:227-234.

30. Tahraoui A, El-Hilaly J, Israili ZH, Lyoussi B: Ethnopharmacological survey of plants used in the traditional treatment of hypertension and diabetes in south-eastern Morocco (Errachidia province). J Ethnopharmacol 2007, 110:105-117.

31. Khalid H, Abdalla WE, Abdelgadir H, Opatz T, Efferth T: Gems from traditional north-African medicine: medicinal and aromatic plants from Sudan. Nat Prod Bioprospecting 2012, 2:92-103.

32. Asase A, Hesse DN, Simmonds MSJ: Uses of multiple plants prescriptions for treatment of malaria by some communities in southern Ghana. J Ethnopharmacol 2012, 144:448-452. 
33. Igoli JO, Ogaji OG, Tor-Anyiin TA, Igoli NP: Traditional medicine practice amongst the igede people of Nigeria. Part II Afr J Trad CAM 2005, 2 (2):134-152.

34. Noumi EPH, Eloumou MER: Syphilis ailment: prevalence and herbal remedies in ebolowa subdivision (south region, Cameroon). Int J Pharm Biomed Sci 2011, 2(1):20-28.

35. Nunkoo DH, Mahomoodally MF: Ethnopharmacological survey of native remedies commonly used against infectious diseases in the tropical island of Mauritius. J Ethnopharmacol 2012, 143:548-564

36. Yaméogo J, Belem-Ouédraogo M, Bayala J, Ouédraogo MB, Guinko S: Uses and commercialization of borassus akeassii bayton, ouédraogo, guinko non-wood timber products in south-western Burkina Faso, west Africa. Biotechnol Agron Soc Environ 2008, 12(1):47-55

37. Rush D: Ephemerality and the "unfinished" in Vodun aesthetics. Afr Arts 2010, 43(1):60-75.

38. Quenum J-C: Education traditionnelle Au bénin, La place du sacré dans Les rites initiatiques. Int Rev Educ 1999, 45(3/4):281-303.

39. Kahn J: Policing 'Evil': state-sponsored witch-hunting in the People's Republic of Bénin. J Religion Afr 2011, 41:4-34.

40. Dransfield J, Uhl NW, Asmussen CB, Baker WJ, Harley MM, Lewis CE: Genera Palmarum: The Evolution and Classification of Palms. London, UK: Kew Publishing; 2008.

41. Johnson DV, Food and Agriculture Organization of the United Nations: Non-Wood Forest Products: Tropical palms. 10/Rev.1. Rome: FAO; 2011.

42. Govaerts R, Dransfield J: World Checklist of Palms. Kew, London: Royal Botanic Gardens; 2005.

43. The International Plant Names Index (IPNI): http://www.ipni.org.

44. Tomlinson PB: The Structural Biology of Palms. New York: Oxford University Press; 1990.

45. Smith EW, Dale AM: The Ila-Speaking Peoples of Northern Rhodesia. 1st edition. London: Macmillan and Co; 1920

46. Nagata JM, JewC AR, Kimeud JM, Salmena CR, Bukusie EA, Cohenf CR: Medical pluralism on Mfangano island: use of medicinal plants among persons living with HIV/AIDS in Suba District, Kenya. J Ethnopharmacol 2011, 135:501-509.

47. Maclean U: Magical Medicine. A Nigerian Case-Study. London: The Penguin Press; 1977.

48. Harley GW: Native African Medicine. With Special Reference to Its Practice in the Mano Tribe in Liberia. London: Frank Cass \& Co. Ltd; 1970.

49. Akendengué $B$, Louis AM: Medicinal plants used by Masango people in Gabon. J Etnopharmacol 1994, 41:193-200

50. Burton RF: A Mission to Gelele, King of Dahome: With Notices of the so-Called "Amazons" the Grand Customs, the Human Sacrifices, the Present State of the Slave Trade and the negro's Place in Nature. London: Tylston; 1893.

51. Adjanohoun EJ, Ahyi AMR, Aké Assi L, Baniakina J, Chibon P, Cusset G, Doulou V, Enzanza A, Eymé J, Goudoté E, Keita A, Mbemba C, Mollet J, Moutsamboté JM, Mpati J, Sita P: Contribution aux Études Ethnobotaniques et Floristiques en République Populaire du Congo. Paris: Médecine Traditionelle et Pharmacopée. Agence de Coopération Culturelle et Technique; 1988.

52. Mabberley DJ: The Plant-Book: A Portable Dictionary of the Higher Plants. Cambridge: Cambridge University Press; 1987:371.

53. Quiroz D, Towns A, Legba SI, Swier J, Brière S, Sosef M, van Andel T: Quantifying the domestic market in herbal medicine in Benin, West Africa. J Ethnopharmacol 2014, 151:1100-1108.

54. Towns AM, Eyi SM, van Andel TR: Traditional medicine and child care in Western Africa: mothers' knowledge, folk illnesses, and patterns of healthcare-seeking behavior. Plos ONE In press.

55. Smith EW, Dale AM: The Ila-Speaking Peoples of Northern Rhodesia. 2nd edition. London: Macmillan and Co; 1920.

56. Altman N: Sacred Trees. San Francisco: Sierra Club Books; 1994

57. Heine B, Heine I: Plant Concepts and Plant use: An Ethno-Botanical Survey of the Semi-Arid and Arid Lands of East Africa: Part 1. Plants of the Chamus (Kenya), Kölner Beiträge zur Entwicklungsländerforschung, Bd. 6 Saarbrücken: Verlag Breitenbach; 1988.

58. Rodin RJ: The ethnobotany of the kwanyama ovambos. Monogr Syst Bot Mo Bot 1985, 9:1-163.

59. Katende AB, Ssegawa P, Birnie A: Wild Food Plants and Mushrooms of Uganda. Kenya: Regional Land Management Unit/Sida; 1999:346-347.

60. Cameroon: Christians celebrate Palm Sunday: http://allafrica.com/stories/ 200803171405.html.
61. Christians in Cape Coast hold church service to mark Palm Sunday: http:// vibeghana.com/2013/03/24/christians-in-cape-coast-hold-church-service-tomark-palm-sunday/.

62. Herlehy TJ: Ties that bind: palm wine and blood-brotherhood at the Kenya coast during the 19th century. Int JAfr Hist Stud 1984, 17(2):285-308.

63. Rush D: In remembrance of slavery. Afr Arts 2011, 44(1):40-51.

64. Sugishita K: Traditional medicine, biomedicine and christianity in modern Zambia. Africa 2009, 79(3):435-453.

65. Tchacondo T, Karou SD, Agban A, Bako M, Batawila K, Bawa ML, Gbeassor $M$, de Souza C: Medicinal plants use in central Togo (Africa) with an emphasis on the timing. Pharmacog Res 2012, 4(2):92-103.

66. Benbadis SR, Chang S, Hunter J, Wang W: The influence of the full moon on seizure frequency: myth or reality? Epilepsy Behav 2004, 5:596-597.

67. Abbink J: Me'en ritual medicinal and other plants: a contribution to south-west Ethiopian ethno-botany. J Ethiopian Stud 1993, 26(2):1-21.

68. Chevalier AJB: Les Végétaux Utiles de I'Afrique Tropicale Française. Paris: 1910:7-66.

69. Juhé-Beaulaton D, Roussel B: Sacred Spaces in Ritual Practices. May Vodun Sacred Spaces be Considered as a Natural Patrimony? In Creating and Representing Sacred Spaces. Edited by Gardner T, Moritz D. Göttingen: Göttinger Beiträge zur Asienforschung Nr. 2-3: Peust and Gutschmidt Verlag; 2003.

70. Moerman DE: Agreement and meaning: rethinking consensus analysis. J Ethnopharmacol 2007, 112:451-460.

71. Young A: Some implications of medical beliefs and practices for social anthropology. Am Anthropol 1976, 78(1):5-24.

72. Corrigan BM, Van Wyk B-E, Geldenhuys CJ, Jardine JM: Ethnobotanical plan uses in the KwaNibela Peninsula, St Lucia, South Africa. S Afr J Bot 2011, 77:346-359.

73. Comaroff J, Comaroff J: Policing culture, cultural policing: law and social order in postcolonial South Africa. Law Social Ing 2004, 29(3):513-545.

74. Magoola R: Engaging witchcraft accusations among christians as a vehicle of African traditional religious self-advocacy in African contexts. Asbury J 2013, 68(1):97-107.

75. Cohan JA: The problem of witchcraft violence in Africa. Suffolk $U L \operatorname{Rev}$ 2011, 64(4):803-872.

76. Meel BL: Witchcraft in Transkei region of south African: case report. Afr Health Sci 2009, 9(1):61-64.

doi:10.1186/1746-4269-10-60

Cite this article as: Gruca et al:: Ritual uses of palms in traditional medicine in sub-Saharan Africa: a review. Journal of Ethnobiology and Ethnomedicine 2014 10:60.

\section{Submit your next manuscript to BioMed Central and take full advantage of:}

- Convenient online submission

- Thorough peer review

- No space constraints or color figure charges

- Immediate publication on acceptance

- Inclusion in PubMed, CAS, Scopus and Google Scholar

- Research which is freely available for redistribution 